\title{
Sandstones and phosphatized calcareous sediments of the Lower Cambrian Rispebjerg Sandstone, Bornholm, Denmark
}

\author{
BY \\ Ada de Marino
}

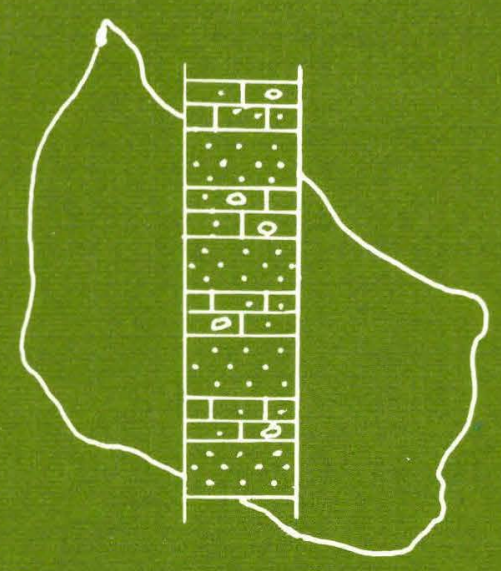

I kommission hos C. A. Reitzels Forlag. København 1980 
Danmarks Geologiske Undersøgelse. II. Række. Nr. 113

Geological Survey of Denmark. II. Series. No. 113

\section{Sandstones and phosphatized calcareous sediments of the Lower Cambrian Rispebjerg Sandstone, Bornholm, Denmark}

By

Ada de Marino

I kommission hos C. A. Reitzels Forlag København 1980 
D. G. U. II. rk. nr. 113

er sat med fotosats Times

og trykt i offset i 1000 eksemplarer

hos AiO Tryk as, Odense

Bogen er trykt på Thai-Cote, $115 \mathrm{~g}$

fra a/s De forenede Papirfabrikker.

ISBN 87-421-0726-1

ISSN 0366-9130

A. de Marino, Geological Survey of Denmark

Thoravej 31, DK-2400 Copenhagen NV, Denmark

Date of publication: 1980-12-11

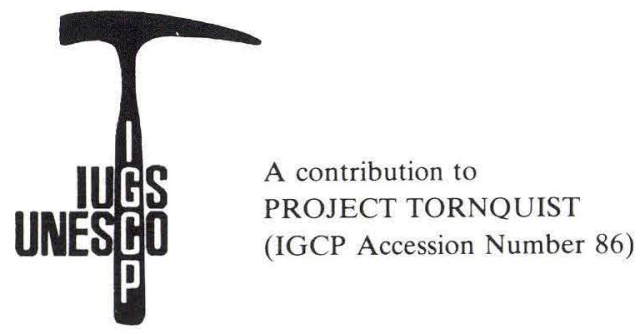




\section{Contents}

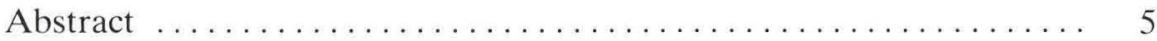

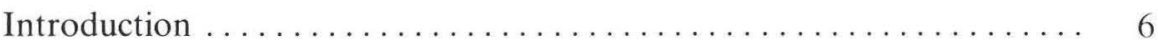

Sampling and laboratory procedures $\ldots \ldots \ldots \ldots \ldots \ldots$

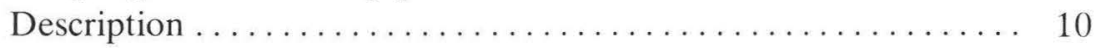

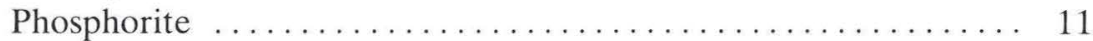

Calcitic submature quartzarenite $\ldots \ldots \ldots \ldots \ldots \ldots \ldots \ldots \ldots \ldots$

Calcitic siliceous submature glauconitic quartzarenite . . . . . . 20

Siliceous submature quartzarenite $\ldots \ldots \ldots \ldots \ldots \ldots \ldots \ldots \ldots \ldots$

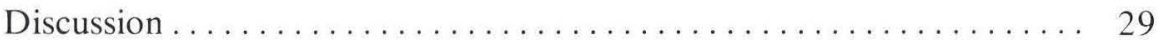

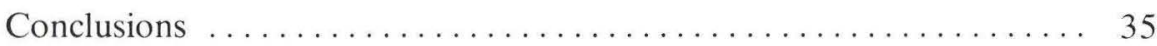

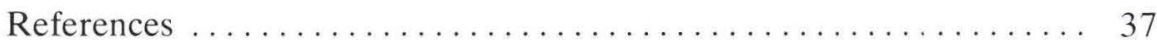




\section{Abstract}

The Rispebjerg Sandstone on the island of Bornholm, Denmark, consists of sandstone layers intercalated with phosphorite layers. The phosphorite lithology is composed of micritic phosphorite containing varying amounts of terrigenous grains and minor amounts of calcareous and non-calcareous allochems. Mineralogically, the micritic phosphorite is chiefly composed of carbonate-apatite, according to X-ray diffractograms. More or less complete calcite replacement by phosphate occurs both in the micrite and in the calcareous allochems. Bioturbation must have been intense as most depositional sedimentary structures have been destroyed. The most plausible explanation of the phosphorite lithology is that calcareous mud was deposited in a barred lagoon in which storms blew back sand from the barrier. Sand and mud were then mixed by bioturbation. Penecontemporaneously with the deposition of this sediment, phosphatization of calcite by phosphorous from sea water is judged to have occurred.

The sandstone lithologies are calcitic siliceous submature glauconitic quartzarenite, calcitic submature quartzarenite and siliceous submature quartzarenite. Gravel-sized grains are present in the two latter sandstone types. All the sandstones are characterized by good roundness $\left(\mathrm{M}_{\mathrm{e}}>3_{\mathrm{e}}\right)$ and moderate sorting $\left(\sigma_{\varnothing}>0,50 \varnothing\right)$. These textural parameters indicate textural inversion. The roundness is interpreted as inherited from older sediments. The sandstones may have been deposited in the tidal complex on the landward side of the sandy barrier.

Scarce calcareous and phosphatic fossil fragments were locally found in rocks of all lithologies. Deposition of the Rispebjerg Sandstone was interrupted by periods of erosion, one of which originated the formation of an intraformational unconformity.

Several diagenetical replacements - phosphatization, chertification, calcification, glauconitization, chloritization, pyritization - occurred during and after deposition of the Rispebjerg Sandstone. 


\section{Introduction}

The Rispebjerg Sandstone crops out in the southern part of the island of Bornholm, Denmark, at the Laeså and Øleå rivulets, and represents the uppermost Lower Cambrian beds on Bornholm (Figs. 1, 2). Cambrian deposits of Bornholm are preserved in the southern part of the island (see review by Martinsson, 1974, with a comprehensive list of references). They were deposited in a relatively shallow sea. Biogeographically, this was part of what was formerly known as the Atlantic or Acado-Baltic province. The Cambrian system on Bornholm is divided into three series which correspond to the Lower, Middle and Upper Cambrian, viz. the Holmia, Paradoxides and Olenid Series. According to Poulsen (1966), the total thickness of the Cambrian on Bornholm (exclusive of the Nexø Sandstone) is estimated at $185 \mathrm{~m}$.

The detailed lithological similarity between the successions in Bornholm and Scania suggests the possibility of a direct lithostratigraphic correlation (Fig. 2), (e.g. Bergström 1970). In the present paper, the division into formations, as well as the zonation, mainly follows recent usage (V. Poulsen 1966; Martinsson 1974; Ahlberg \& Bergström 1978). The Cambrian age of the Nexø and Balka Sandstones may be questioned, at least as long as there is no international agreement on the position of the Venedian-Cambrian boundary (cf. Jensen 1977).

The Rispebjerg Sandstone has been dealt with by Johnstrup $(1874,1891)$, Deeke (1897, 1899), Grönwall (1899, 1902), Grönwall \& Milthers (1916) and Hansen (1936) amongst others. According to these authors, the formation is made up of a ferruginous, loose, porous, coarse quartzitic sandstone, of about $3 \mathrm{~m}$ thickness, the uppermost $40 \mathrm{~cm}$ of which are impregnated with black phosphorite and referred to as phosphorite sandstone. Hansen (1937) made a more detailed description of the Rispebjerg Sandstone and correlated a pyritic layer of this sandstone found at Øleå in his locality 6 , with the pyrite conglomerate overlying the Kalby Clay at Laeså, (cf. V. Poulsen 1963). Accordingly, Hansen considered the clay bed and the overlying pyrite conglomerate at Laeså to belong to the Rispebjerg Sandstone. The clay bed was interpreted by Grönwall (1902) and C. Poulsen (1942) as weathered Exsulans Limestone.

The Rispebjerg Sandstone is described by Sorgenfrei (1957) as a greyish- 


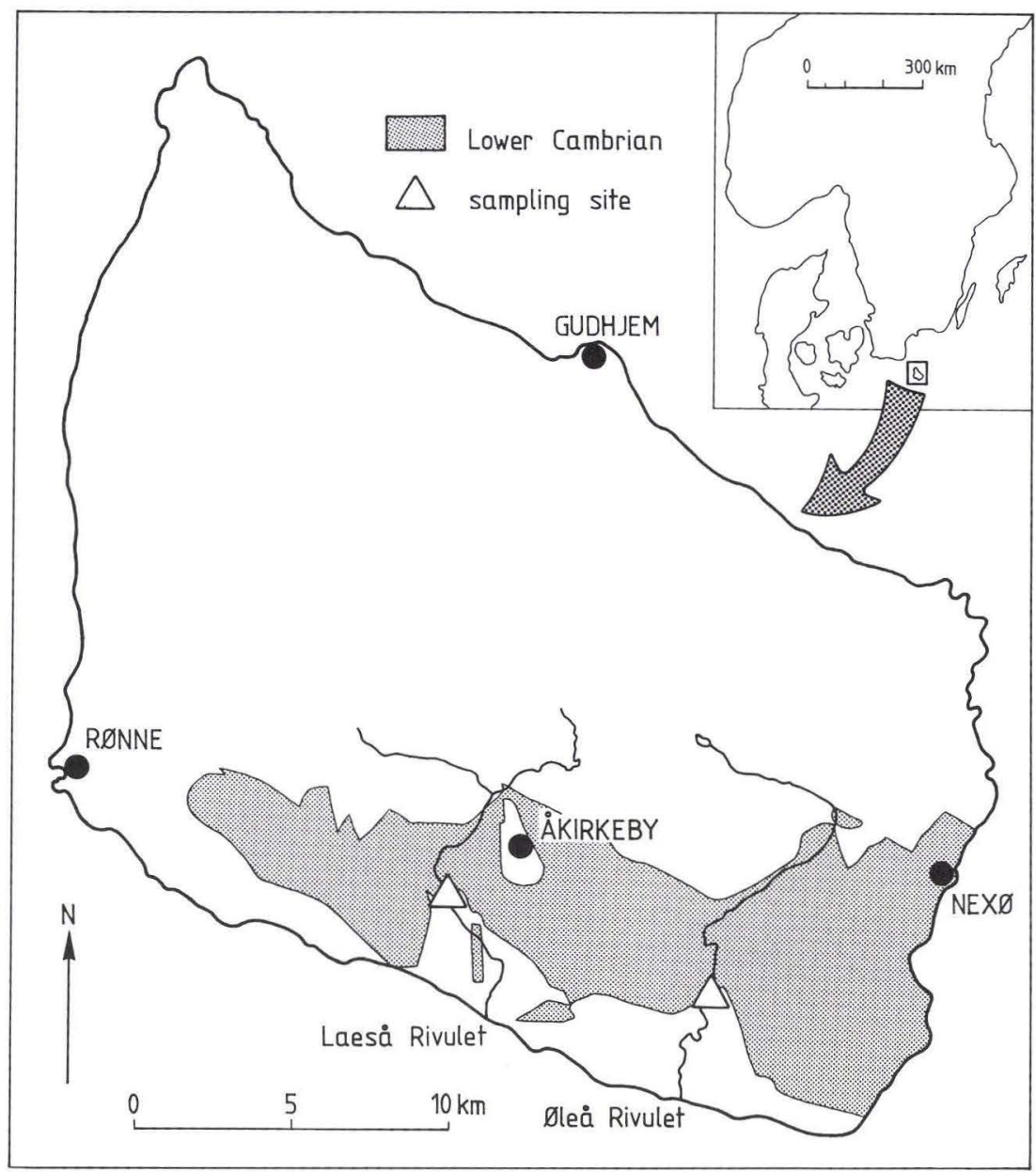

Fig. 1. Map showing sub-Quaternary distribution of Lower Cambrian and the sampling sites $(\triangle)$ at Laeså and Øleå Rivulets on Bornholm, Denmark. Map modified from Gry (1969) with editor's permission.

-white quartzitic sandstone overlain by a dark phosphoritic sandstone. According to Sorgenfrei, the phosphorite is thought to have been segregated »posthumously« during the Middle Cambrian transgression. Furthermore, glauconite and pyrite are said to occur near the base of the upper unit and the Rispebjerg Sandstone was considered to be unfossiliferous. However, Poulsen (1967) reported a trace fossil (Cruziana dispar) and a specimen of Hyolithellus micans Billings, the latter possibly reworked.

As a result of the present investigation, the following lithologies have been 


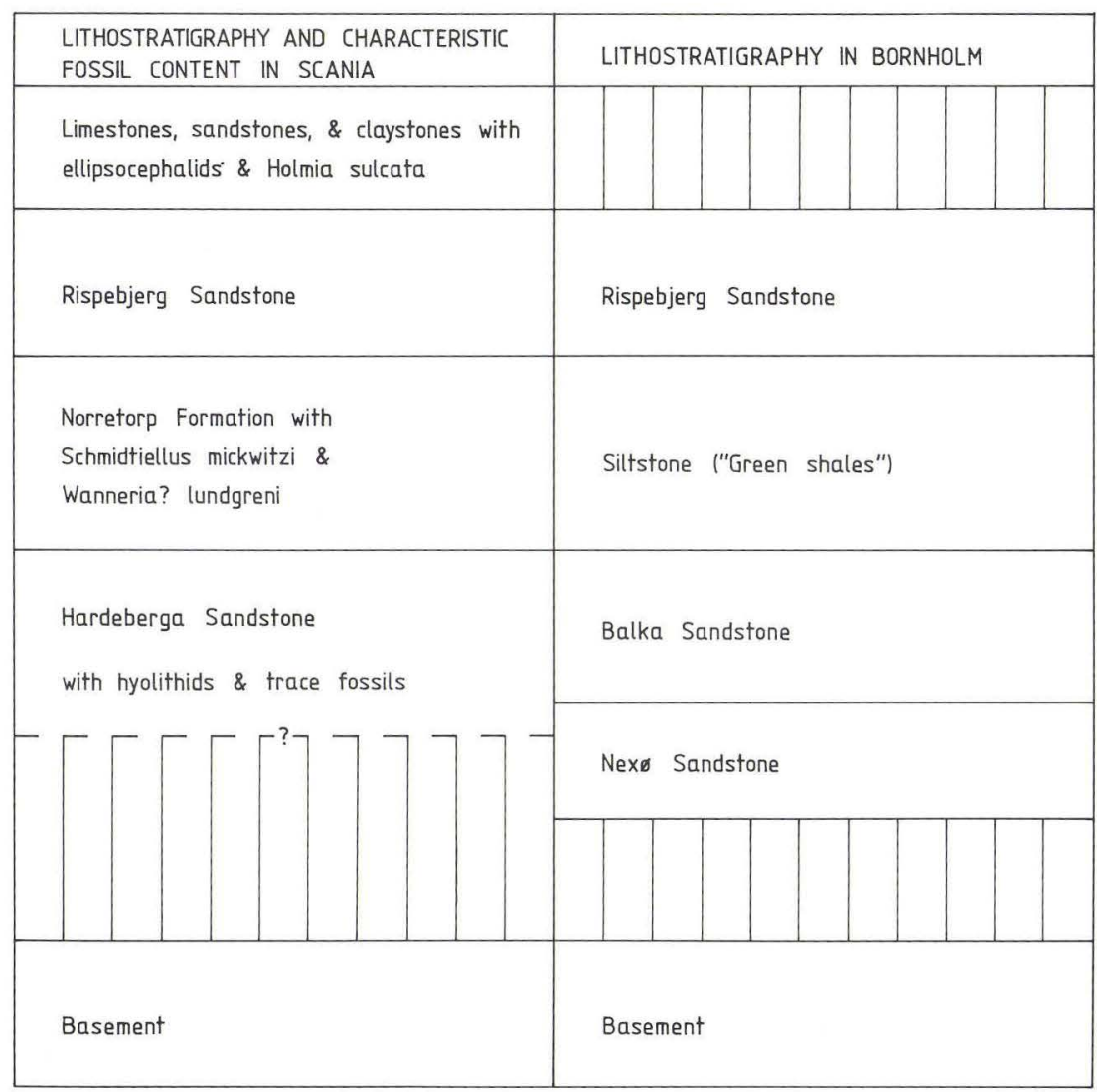

Fig. 2. Diagram showing the Lower Cambrian (and uppermost Vendian?) of Bornholm and suggested correlation with Scania (see discussion in the text).

recognized in the Rispebjerg Sandstone, namely: phosphorite, calcitic submature quartzarenite, siliceous submature quartzarenite and calcitic siliceous submature glauconitic quartzarenite, the latter being the most basal lithology.

\section{Sampling and laboratory procedures}

For this study, 49 thin sections from 38 samples were analyzed. The samples were collected from three localities (Figs. 3, 4). Thin sections were made by conventional methods, but in cases where the samples were partially friable, they were impregnated with resin prior to sectioning. Rock composition of 40 thin sections was determined. For mineral analyses, polarization microscope, 
Fig. 3. Detailed map showing the position of locality 1 at Laeså Rivulet in Bornholm, Denmark.

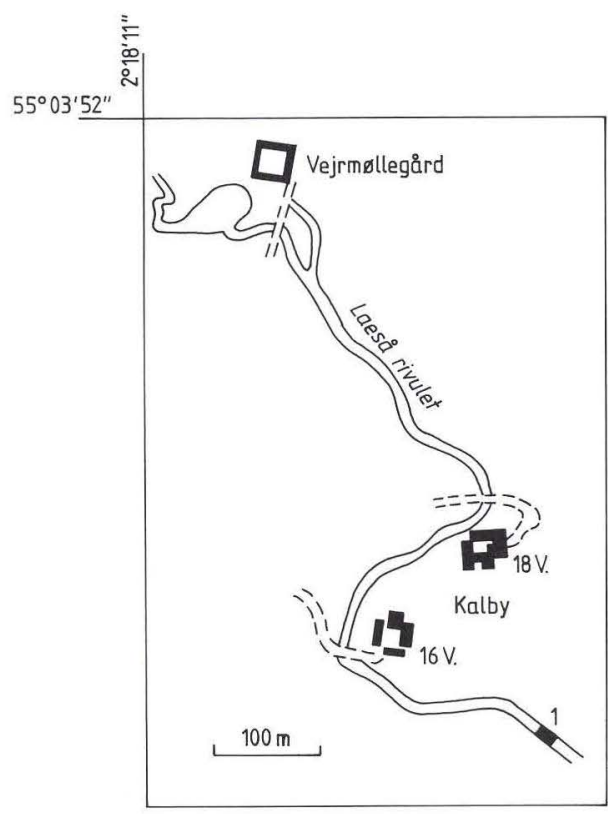

X-ray diffractometry and energy dispersive X-ray spectrometer (EDS) connedted with an electron microscope were used. The mineral content was obtained by point counting following the technique described by Glagolev (1933, 1934). Between 300 and 500 points were counted in each slide.

Grain-size distribution of 22 thin sections corresponding to the sandstone

Fig. 4. Detailed map showing the positions of localities 2 and 3 at Øleå Rivulet in Bornholm, Denmark.

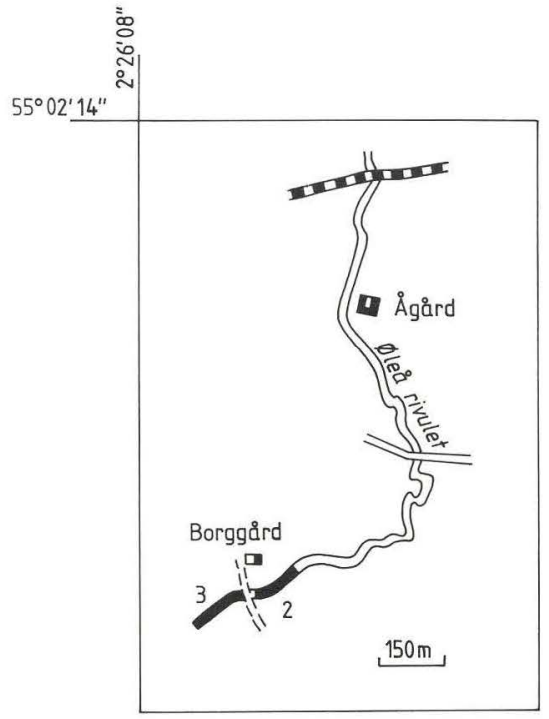


lithologies was determined following the method described by Friedman (1958) and the graph-paper developed by this author for conversion from thin-section values to sieve-size equivalents was utilized. Between 300 and 500 counts were made in each thin section. Cumulative frequency curves were constructed on probability paper so that the accuracy of the 5 th, 16th, 84 th and 95 th percentiles could be easily determined. The statistic parameters $\left(\mathrm{M}_{\mathrm{z}}, \sigma_{\mathrm{I}}\right)$ were calculated with the Folk \& Ward (1957) formulas by graphic method and the scale of sorting values by the same authors was followed. Grain roundness of 35 thin sections was estimated using the visual estimation charts of Powers (1953). Counts of 100 Grains were made in each thin section. The Rho scale of Folk (1955) was used to calculate the mean roundness $\left(\mathrm{M}_{\mathrm{e}}\right)$ and the standard deviation of roundness $\left(\sigma_{\mathrm{e}}\right)$, following the limits given by Folk (1974) for the roundness standard deviation.

For classification, the triangular diagram and grain-size nomenclature of Folk (1954) for terrigenous sediments and sedimentary rocks, and Folk's (1974) triangular diagram for main division of sedimentary rocks were followed. The sandstone classification proposed by Folk (1974) and Folk et al. (1970) was followed. The colour symbols are according to the Rock-Color Chart (1970).

\section{Description}

Outcrops of the contact between the Rispebjerg Sandstone and the underlying »Green Shale« are not available. Generally, this formation constitutes the bottom of the rivulets in the localities studied. In the Ølea rivulet, however, the outcrops of Rispebjerg Sandstone alternate with those from Middle Cambrian. Good and continuous exposure of the different lithologies are rare, due to faulting, differential erosion and covering by water from the rivulets or by glacial deposits.

Most of the samples were taken at or under the water level because of the lack of good vertical exposures. This also made it difficult to observe sedimentary structures and to make exact thickness measurements of the different lithologies. For practical reasons I have called the most basal of the phosphorite layers, 'phosphorite I', the intermediate layer, 'phosphorite II' and the uppermost layer, 'phosphorite III'. Locality 1 is the only place where the siliceous quartzarenite is well-exposed, with vertical sections reaching about $2 \mathrm{~m}$ or so in height. The siliceous quartzarenite also constitutes the rivulet bottom at Laeså, where it grades upwards into the phosphorite II layer which in turn forms the bottom of the rivulet downstream. At locality 2 , there are no significant vertical exposures. Here, as at locality 1 , different litho- 
logies constitute the rivulet bed. At this locality only a few cms of the calcitic quartzarenite are exposed. This lithology grades upwards into $7 \mathrm{~cm}$ or so of phosphorite I, which in turn is overlain with sharp contact by up to approximately $8 \mathrm{~cm}$ of siliceous quertzarenite. At locality 3 , a more complete sequence is found. Here, is the only place where the calcitic siliceous submature glauconitic quartzarenite is observed. Lying at the bottom of the strata it is normally covered by the rivulet. At one spot only in this locality was the lithology exposed, showing low-angle cross strata and horizontal lamination. This is the most basal lithology of the sequence, grading upwards into the calcitic quartzarenite, which in turn has a sharp contact with an overlying layer of siliceous quartzarenite. The latter grades upwards into the phosphorite layer II, most of which has been eroded. The overlying, uppermost layer of phosphorite III, of up to $12 \mathrm{~cm}$ or so, with a sandy level at its base, has erosive contact with the underlying lithologies. The whole thickness of the strata at this locality is about $55 \mathrm{~cm}$.

\section{Phosphorite}

As has been previously described, this lithology was found at three different stratigraphical levels within the Rispebjerg Sandstone. Although there are slight structural and mineralogical differences between these phosphorite layers, they will be discussed together and only the differences will be treated separately.

These phosphorite layers are macroscopically rather similar, but while in the phosphorite I and III, bioturbational activity has destroyed most of the original sedimentary structures, several samples of the phosphorite II show horizontal lamination where mm-laminae of almost pure micritic phosphorite alternate with laminae of pure sand or with laminae in which the proportion of terrigenous detritus embedded in the micritic phosphorite is around $50 \%$. Allochthonous glauconite grains were only found in the uppermost layer. The sandy level at the base of phosphorite layer III consists of muddy sand which in some parts is weakly consolidated while in others it is cemented by calcite. Gravel-sized phosphorite intraclasts and well-rounded pebbles, with the composition of the underlying siliceous sandstone, occur embedded in the sandy level. Pyrite is common in phosphorite layers I and III, being very abundant in the latter, whereas it is absent or present only in small amounts in phosphorite layer II. The rocks belonging to this lithology are hard and compact with a characteristic black colour (N1), although in samples of phosphorite II, where lamination is preserved, a moderate brown colour (5YR 4/4) and a slight friability is present in the sand-rich layers. 


\begin{tabular}{|c|c|c|c|c|c|c|c|c|c|c|c|c|c|}
\hline Samples & 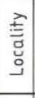 & $\begin{array}{c}\text { Terrigenous } \\
\%\end{array}$ & $\begin{array}{c}\text { Calcareous } \\
\text { allochems } \\
\%\end{array}$ & $\begin{array}{l}\text { Non- } \\
\text { calcareous } \\
\text { allochems } \\
\%\end{array}$ & $\begin{array}{c}\text { Orthochems } \\
\%\end{array}$ & $\begin{array}{l}\text { 점 } \\
\text { 음 } \\
\text { 플 }\end{array}$ & Samples & 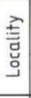 & $\begin{array}{c}\text { Terrigenous } \\
\%\end{array}$ & $\begin{array}{c}\text { Calcareous } \\
\text { allochems } \\
\%\end{array}$ & $\begin{array}{l}\text { Non- } \\
\text { calcareous } \\
\text { allochems } \\
\%\end{array}$ & $\begin{array}{c}\text { Orthochems } \\
\%\end{array}$ & 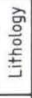 \\
\hline Bo-G-15a & 3 & 40.40 & 0.80 & 16.40 & 42.40 & 1 III & Bo-E - $2 g$ & 3 & 62.57 & 0.85 & 10.00 & 26.57 & 3 \\
\hline Bo $-F-2$ & 3 & 18.00 & 0.20 & 6.20 & 75.60 & $1 \mid 11$ & Bo-F-1d & 3 & 62.37 & 2.10 & 7.09 & 28.42 & 3 \\
\hline$B o-F-3 a$ & 3 & 27.40 & & 11.80 & 60.80 & $1 ॥$ & Bo-F-15 & 3 & 55.80 & 2.60 & 10.80 & 30.80 & 4 \\
\hline Bo-F- 11 & 3 & 40.60 & & 7.00 & 52.40 & $1 ॥$ & $B o-F-1 a$ & 3 & 58.40 & & 8.60 & 33.00 & 4 \\
\hline$B o-F-16 a$ & 1 & 45.45 & 1.50 & 0.25 & 52.75 & 111 & Bo-F-7 & 3 & 63.40 & & 7.20 & 29.40 & 4 \\
\hline Bo-A-10 & 1 & 33.03 & 1.51 & 1.51 & 63.93 & 11 & Bo-D-11 & 2 & 67.20 & 0.40 & 10.20 & 22.20 & 4 \\
\hline$B o-D-3$ & 1 & 51.67 & 4.67 & 0.66 & 43.00 & 111 & $B o-A-11$ & 2 & 55.00 & & 7.75 & 37.25 & 4 \\
\hline Bo-D-2 & 1 & 63.99 & 3.00 & & 33.00 & १॥ & Bo-G-11 & 3 & 63.00 & & 4.20 & 32.80 & 4 \\
\hline$B o-D-4$ & 1 & 61.00 & & 0.25 & 38.75 & 1II & Bo $-F-12$ & 3 & 69.87 & & 3.38 & 26.75 & 4 \\
\hline Bo-G-10 & 3 & 51.77 & & 0.22 & 48.21 & 111 & Bo-F-14 & 3 & 78.89 & & 0.50 & 20.59 & 4 \\
\hline$B o-D-6 a$ & 2 & 47.25 & 12.00 & 4.50 & 36.50 & 11 & $B o-G-9$ & 3 & 79.71 & & 1.08 & 19.19 & 4 \\
\hline$B o-A-13 a$ & 2 & 45.00 & 6.60 & 2.60 & 45.80 & 1 & $B 0-F-13 a$ & 3 & 67.75 & 1.25 & 1.25 & 29.75 & 4 \\
\hline Bo-D-8 & 2 & 44.22 & & 1.11 & 54.66 & 1 & $B O-A G-8$ & 1 & 86.93 & & & 13.05 & 4 \\
\hline$B 0-A-12$ & 2 & 35.60 & 0.60 & 19.80 & 43.60 & 11 & Bo-A-1 & 1 & 85.00 & & 0.20 & 14.80 & 4 \\
\hline Bo-F-1b & 3 & 80.66 & 1.33 & 0.66 & 17.33 & 2 & Bo-A-2 & 1 & 82.60 & & & 17.40 & 4 \\
\hline$B o-F-1 c$ & 3 & 64.00 & 1.00 & 4.60 & 30.40 & 2 & Bo $-A-3$ & 1 & 84.20 & & 0.40 & 15.40 & 4 \\
\hline $\mathrm{Bo}-\mathrm{A}-13 \mathrm{~b}$ & 2 & 48.67 & 0.89 & 16.21 & 34.21 & 2 & $B o-A-4$ & 1 & 91.00 & & 0.80 & 8.20 & 4 \\
\hline$B o-D-6 b$ & 2 & 68.88 & 0.56 & 0.85 & 29.70 & 2 & Bo $-A-5$ & 1 & 85.60 & & 0.40 & 14.00 & 4 \\
\hline$B o-i-3$ & 3 & 68.20 & 0.40 & 1.00 & 30.40 & 2 & $B o-A-6$ & 1 & 85.20 & & 0.60 & 14.20 & 4 \\
\hline Bo $-F-8$ & 3 & 65.33 & 1.33 & 4,44 & 28.88 & 3 & $\mathrm{Bo}-\mathrm{A}-9$ & 1 & 84.60 & & 0.60 & 14.80 & 4 \\
\hline
\end{tabular}

Table I. Rock composition of the lithologies present in the Rispebjerg Sandstone. Lithology No. 1: phosphorite; lithology No. 2: calcitic submature quartzarenite; lithology No. 3: calcitic siliceous submature glauconitic quartzarenite; lithology No. 4: siliceous submature quartzarenite.

Fig. 5. Phosphorite. A. Sample: Bo-F-2, locality 3, plane polarized light, $\times 15$; quartz grains and a phosphorite intraclast embedded in micritic phosphorite. Note the microstylolitic seam at the upper left of the picture. B. Sample: Bo-A-12, locality 2, plane polarized light, $\times 15$; terrigenous grains, calcareous skeletal elements and phosphatic fragments, some of which are probably of organic origin, embedded in micritic phosphorite. C. Sample: Bo-A-10, locality 1, crossed nicols, $\times 95$; microstylolitic seam lined by microcrystalline calcite. The irregular outline of the peloid at the lower right is due to phosphate replacement. Slight chertification affects the micritic phosphorite and the micrite. D. Sample: Bo-D-3, locality 1, plane polarized light, $\times 15$; detrital quartz, one phosphorite intraclast and anastomosing microstylolitic seams in the micritic phosphorite. Note the irregular and anomalous shape of many of the quartz grains in contact with the microstylolitic seams. E. Sample: Bo-D-2, locality 1 , crossed nicols, $\times 38$; quartz sand and peloids embedded in micrite practically replaced by carbonate-apatite. The peloid at the left of the picture is partially replaced by phosphate. F. Sample: Bo-A-13a, locality 2, crossed nicols, $\times 15$; quartz grains, peloids and recrystallized fossil fragments, embedded in micritic phosphorite. The peloids have been replaced to a varying degree by phosphate. The right end of the recrystallized fossil at the centre of the picture has become partially broken. G. Sample: Bo-D-6a, locality 2 , crossed nicols, $\times 38$; detrital quartz together with rhombic and prismatic skeletal plates embedded in micritic phosphorite. Note the micritic envelope on some of them. H. Sample: Bo-A-12a, locality 2, crossed nicols, $\times 15$; obliterated calcareous fossil. Some chambres are partially filled by calcite while others by micritic phosphorite. 

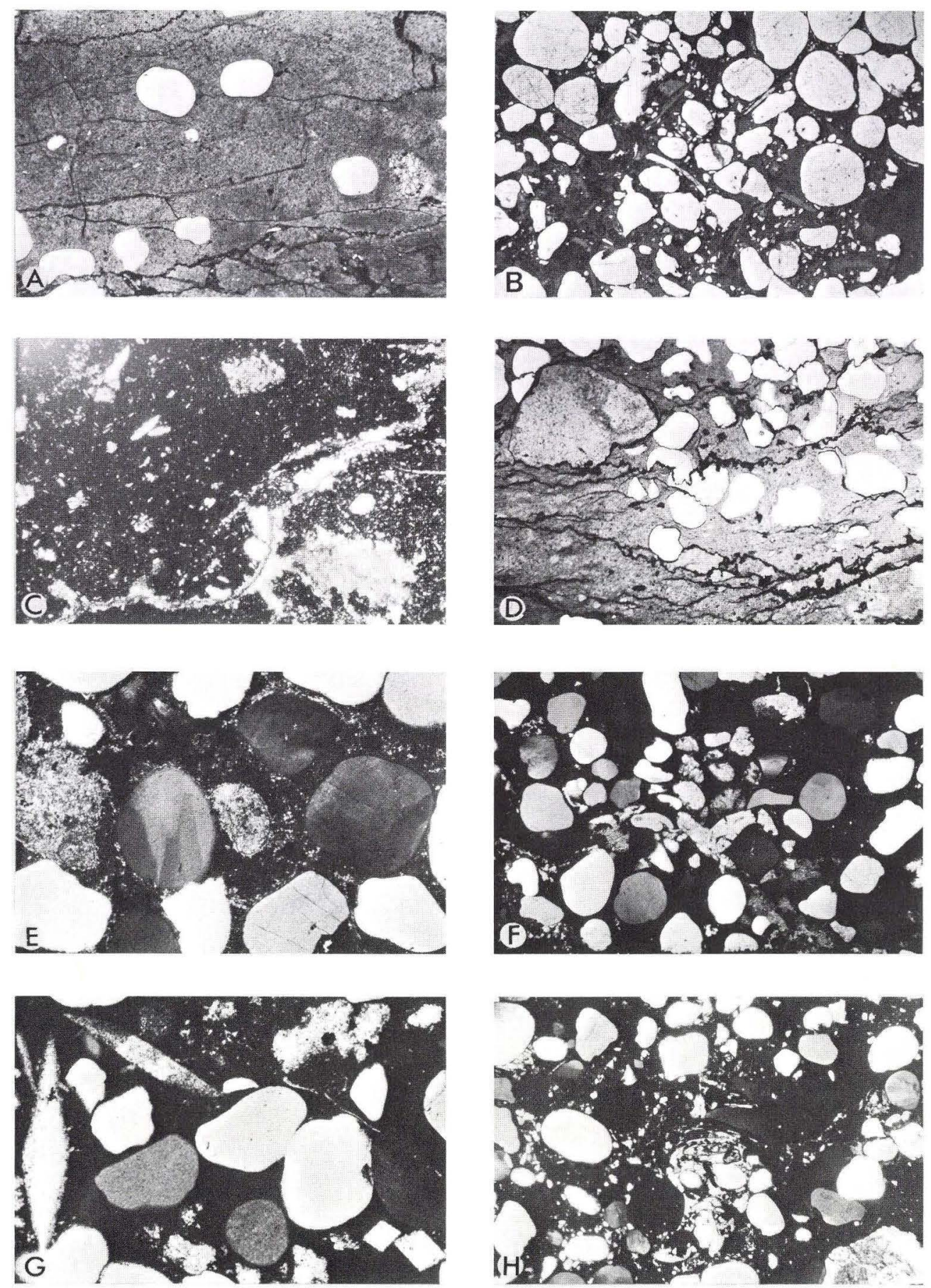


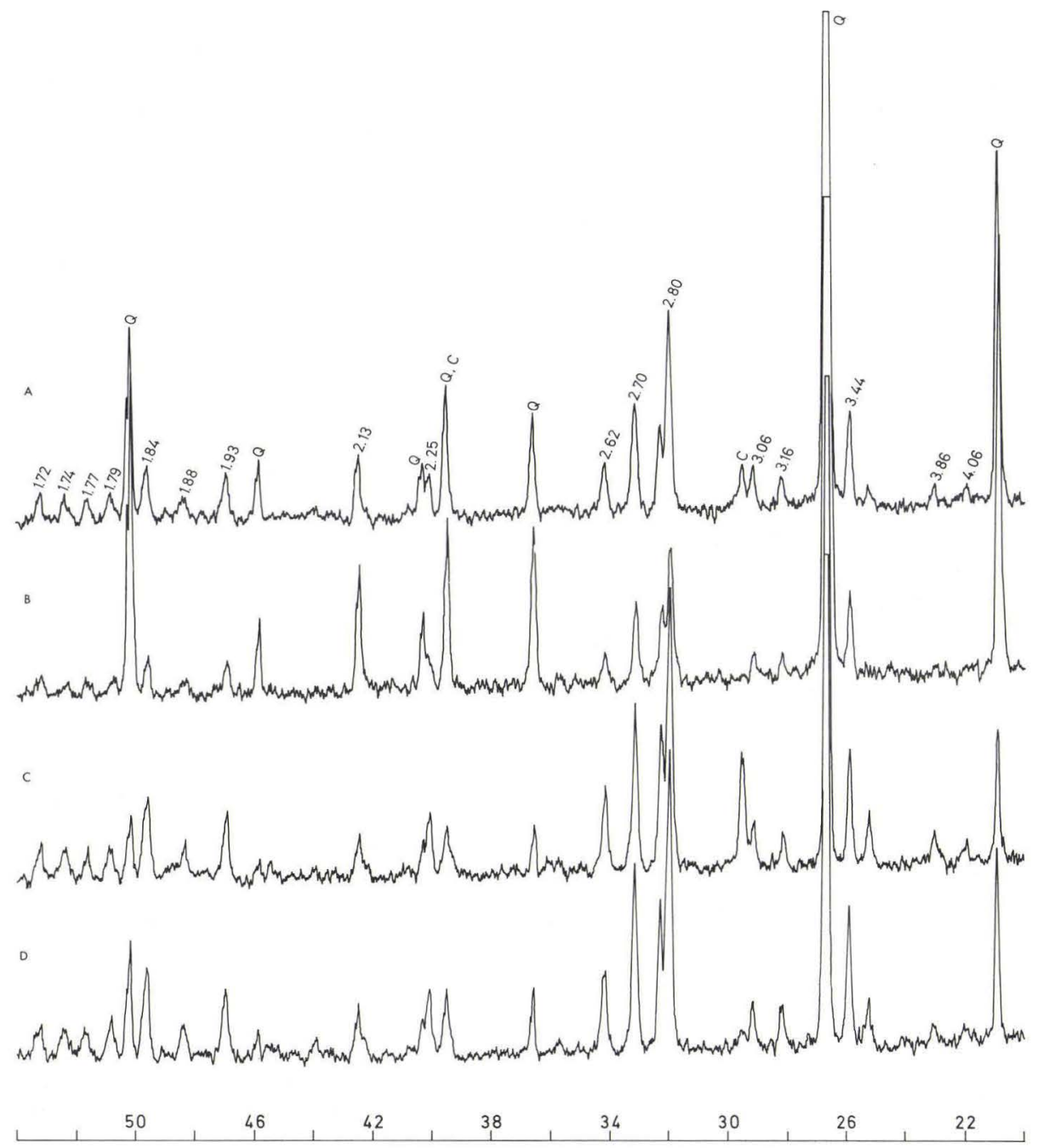

Fig. 6. X-ray diffractograms of four powdered samples of phosphorite. CuKa radiation at $40 \mathrm{kv}$, 20 ma. Abbreviations: $\mathrm{C}$ - minor calcite peaks; $\mathrm{Q}$ - quartz peaks corresponding to the detrital quartz embedded in the micritic phosphorite; all other peaks for carbonate-apatite.

In thin section the rock is seen to be composed of micritic phosphorite which usually contains variable amounts of terrigenous grains and minor amounts of allochems (Fig. 5A, B; Table I). Furthermore, several orthochemical minerals occur to varying degrees. The micritic phosphorite is composed of carbonate-apatite, according to X-ray diffractograms ( $\mathrm{Cu}, \mathrm{K \alpha}$; Fig. 6). The carbonate-apatite gave intense diffraction peaks at 262, 280 and $344 \mathrm{pm}$ 
and many other peaks which correspond to the values for the apatite group given by McConnell (1938) and for marine phosphatized sediment given by Hamilton \& Rex (1959). Varying small amounts of microcrystalline calcite, as well as terrigenous clay, are closely mixed with the micritic phosphorite in some samples.

The terrigenous components vary widely in size, packing and sorting and in general are irregularly distributed in the rock. The silt particles are angular while the mean roundness $\left(\mathrm{M}_{\mathrm{e}}\right)$ of the sand grains ranges from sub-rounded to rounded (3.0 to $5.0_{\mathrm{e}}$ ) and the roundness sorting ranges from very-good to good $\left(<0,60\right.$ to $\left.0,80_{\mathrm{e}}\right)$. Originally-rounded sand grains have occasionally been split during transport. The sand fraction dominates in the terrigenous components in all the samples, but silt and gravel-size grains are locally present, generally in very low amounts.

Quartz is the chief mineral of the terrigenous fraction, but a very few feldspar grains, sedimentary rock fragments and heavy minerals were also noticed. Quartz with corroded and embayed edges, and in cases partially replaced by calcite, occurs. Microstylolitic seams generally lined with microcrystalline calcite and/or pyrite are developed in several samples (Fig. 5C). The terrigenous silicates in contact with these microstylolitic seams have developed sutured edges. In many cases, originally well-rounded quartz grains have been reduced to less than half their original size (Fig. 5D). Pressure solution involving stylolitization is thought to be the main mechanism of compaction and cementation in micrites (Beales 1971).

The calcareous allochems are represented by varying amounts of fossil debris and peloids. McKee \& Gutschich (1969) defined peloids as grains composed of microcrystalline or cryptocrystalline calcite, irrespective of origin, which are rounded but of variable shapes and sizes. The peloids, of silt and sand-size, composed of micrite - in general recrystallized - have different shapes but always good roundness. In the peloids, glauconitization, silification, phosphatization and pyritization occur, the latter even in samples where pyrite is not so common within the matrix. Glauconitization occurs only in phosphorite layer III. Phosphatization of the peloids, to varying degrees, has left irregular calcite patches within the micritic phosphorite, although in most cases it is possible to recognize the original grain boundaries (Fig. 5E).

Calcareous fossils are mostly seen as transversal sections of simple and chambered shells, skeletal plates, recrystallized fossil fragments (Fig. 5F) and prismatic or rhombic plates, generally composed of one single crystal (Fig. $5 \mathrm{G})$. Micrite envelopes have been observed in several fossil fragments. The envelope is believed to form as a result of the precipitation of carbonate in discarded algal bores (Bathurst 1971). The cavities or chambers within the 
calcareous fossils are generally filled by micritic phosphorite or by calcite (Fig. $5 \mathrm{H})$.

Folk $(1959,1962)$ defined intraclasts as fragments of penecontemporaneous, generally weakly consolidated carbonate sediment that has been eroded from adjoining parts of the sea bottom and redeposited to form a new sediment. That is, they have been reworked from within the area of deposition and within the same formation. Intraclasts may be produced by erosion of sedimentary layers almost immediately after they have been laid down, when the sediment is still very plastic and barely cohesive. I consider this mechanism to be the origin of the phosphorite clasts embedded in phosphatic as well as non-phosphatic lithological surroundings. Because of this, the term 'intraclast' is used in this paper to refer to these phosphorite clasts. The non-calcareous allochems are represented by phosphatic fossils (Fig. 7A), phosphatic fragments, glauconite grains and phosphorite intraclasts in varying proportions. Chambers or cavities within phosphatic fossil fragments are filled by either micritic phosphorite or authigenic megaquartz (Fig. 7B). The latter occurs only in the phosphorite III layer. The sand-sized phosphatic fragments are structureless but their outline in most cases suggests an organic origin for them (Fig. 7C).

The phosphorite intraclasts of sand and gravel-size are generally of irregular shape and lack good roundness (Fig. 7D). The rounded sand-sized glauconite grains present in the phosphorite layer III (5-9\%) cause the rock to take on a very slight green shade. In certain instances, this mineral has been oxidized, acquiring a brownish-yellow colour. Partial replacement of the glauconite grains by phosphate has left irregular patches of this mineral within the micritic phosphorite (Fig. 7E).

Slight chertification of the micritic phosphorite has been observed in seve-

Fig. 7. Phosphorite. A. Sample: Bo-A-13a, locality 2, plane polarized light, $\times 95$; phosphatic shell fragment and quartz sand. B. Sample: Bo-F-3a, locality 3 , plane polarized light, $\times 38$; most cavities of the phosphatic fossil fragments are filled by authigenic silica. C. Sample: Bo-A-10, locality 1 , plane polarized light, $\times 38$; detrital silt and sand embedded in micritic phosphorite. The phosphatic fragment at the centre of the picture may be a transversal section of a trilobite skeletal element. D. Sample: Bo-A-12, locality 2, plane polarized light, $\times 15$; quartz sand and phosphorite intraclasts. Note the variable size and shape of the latter and the lack of good roundness. E. Sample: Bo-F-2, locality 3, crossed nicols, $\times 38$; detrital quartz and glauconite grains within the micritic phosphorite. Partial replacement of the glauconite by phosphate has left irregular patches of this mineral. F. Sample: Bo-F-3, locality 3 , crossed nicols, $\times 38$; cracks across both the micritic phosphorite and the glauconite grains were filled with authigenic silica. G. Sample: Bo-F-3, locality 3, plane polarized light, $\times 95$; glauconite grain partially replaced by chlorite. Subsequent development of authigenic pyrite replacing the chlorite, glauconite, phosphate and quartz. H. Sample: Bo-F-11, locality 3 , plane polarized light, $\times 38$; authigenic pyrite acting as cement and strongly attacking the quartz sand. 

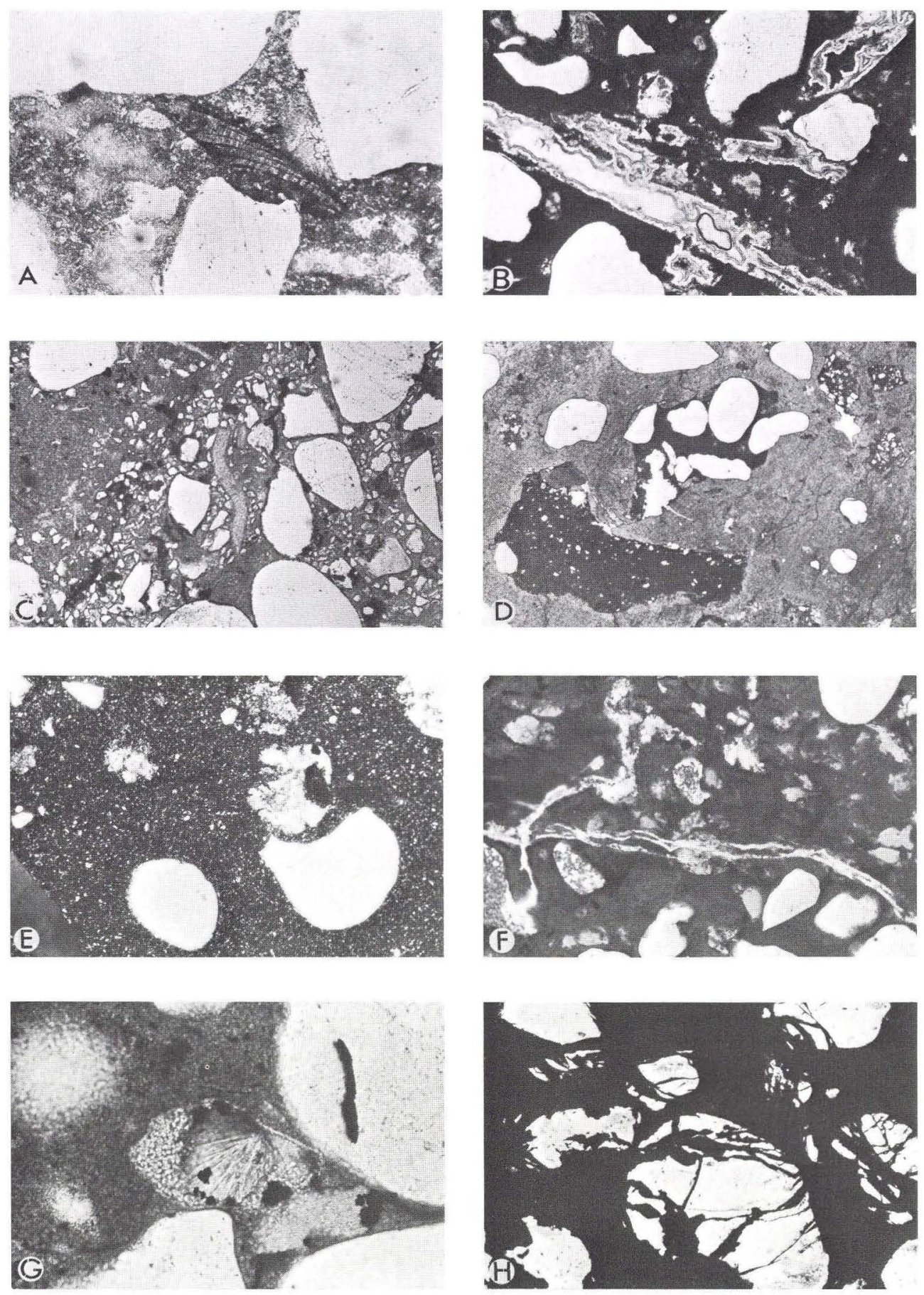
ral samples. The authigenic megaquartz in phosphorite III also fills cracks across both the micritic phosphorite and the glauconite grains (Fig. 7F). Slight chloritization of micritic phosphorite and glauconite grains (Fig. 7G), as well as small irregular patches of sparry calcite, were observed. Tiny amounts of calcite dissolution leave secondary porosity. Pyrite as dust, small cubic crystals of up to sand-size, or in irregular masses replacing the other minerals, is in some instances abundant (Fig. $7 \mathrm{H}$ ).

Calcite, glauconite, phosphate, chlorite, silica and pyrite are the orthochemical components. Thus, on the basis of the different replacements which have taken place in the phosphorite lithology, it seems that the paragenesis of the diagenetical replacements is as follows:

$$
\begin{aligned}
& 1 \text { - Phosphatization } \\
& 2 \text { - Glauconitization (only in phosphorite III) } \\
& 3 \text { - Calcification } \\
& 4 \text { - Silification } \\
& 5 \text { - Chloritization } \\
& 6 \text { - Pyritization }
\end{aligned}
$$

\section{Calcitic submature quartzarenite}

This lithology grades downwards into the underlying glauconitic sandstone and upwards into the overlying phosphorite I. As the changes to the underand overlying lithologies is gradual, it is somewhat difficult to determine the

Fig. 8. Calcitic submature quartzarenite. A. Sample: Bo-D-6b, locality 2, crossed nicols, $\times 38$; quartz grains and one recrystallized fossil fragment cemented by calcite. B. Sample: Bo-A-13b, locality 2 , crossed nicols, $\times 38$; the peloid at the centre of the picture has a difused edge due to the fact that the calcitic grain has been incorporated in the cement and both have the same optical orientation. C. Sample: Bo-G-3, locality 3, crossed nicols, $\times 15$; several quartz grains embedded in one single poikilitic calcite crystal. The dusty inclusions in the neomorphic spar are relics of material now included in the cement. D. Sample: Bo-A-13b, locality 2 , crossed nicols, $\times$ 38; quartz sand showing corroded and embayed edges are embedded in recrystallized calcareous matrix. Calcitic siliceous submature glauconitic quartzarenite. E. Sample: Bo-E-2, locality 3, crossed nicols, $\times 38$; coarse to very fine sand and glauconite. Note the glauconite grain at lower centre of picture, partially squeezed between the surrounding terrigenous detritus which is tightly packed and has sutured contacts. The silica cement is in optical continuity with the detrital quartz. F. Sample: Bo-F-8, locality 3 , crossed nicols, $\times 38$; obliterated calcareous fossil engulfed by the neomorphic spar. The walls of the chambers have been partially destroyed and the chambers are empty. G. Sample: Bo-F-1d, locality 3, crossed nicols, $\times 95$; glauconite filling the chambers of the calcareous fossil and partially replacing the shell. H. Sample: Bo-F-1d, locality 3 , crossed nicols, $\times 95$; in this calcareous fossil, glauconite has first filled the chambers and partially replaced the shell. Later, calcite cement transected the allochems and replaced the glauconite. Note the cleavage lines of the sparry calcite continuing into the chamber of the fossil. 

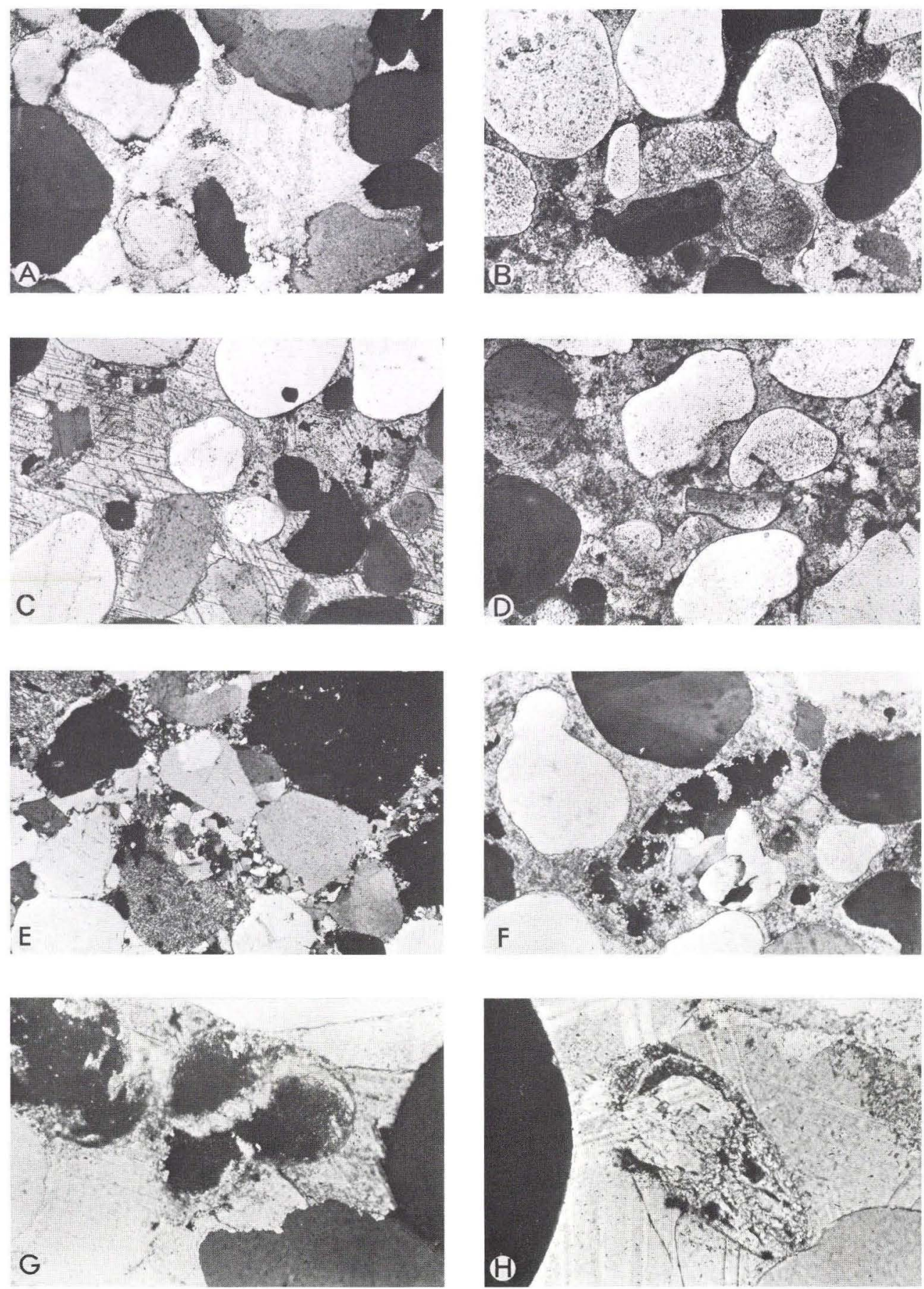
exact boundaries between the lithologies in question. Where phosphorite I was eroded, the calcitic sandstone is directly overlain with sharp, erosive contact by the siliceous sandstone. In hand specimens the calcitic sandstone is light to medium grey (N7 to N5). Very low amounts of black phosphorite intraclasts of sand and gravel-size are usually present throughout this lithology, increasing in quantity towards the top. Texturally, the lithology is moderately sorted $\left(\sigma_{\varnothing}: 0,50\right.$ to $\left.1,00 \varnothing\right)$, medium sandstone $\left(M_{\mathrm{z}}: 1\right.$ to $\left.2 \varnothing\right)$ (Table II). Those with gravel content are slightly conglomeratic - $(\mathrm{g}) \mathrm{S}: 0,01$ to $5,00 \%$ gravel - or conglomeratic - gS : 5,00 to $30,00 \%$ gravel. Sparsely scattered silt particles were seen in only two thin sections. The mean roundness $\left(\mathrm{M}_{\mathrm{e}}\right)$ ranges from sub-rounded to rounded and the roundness standard deviation $\left(\sigma_{\mathrm{e}}\right)$ ranges from good to very-good roundness sorting.

Microscopically, the rocks are composed chiefly of terrigenous detritus, containing, also, fewer and variable amounts of allochems, cemented by neomorphic sparry calcite (Table I). Neomorphism is a collective term proposed by Folk (1965) for both inversion (of aragonite) and recrystallization (of other kinds of calcite), or where the exact process is not know.

Most of the terrigenous detritus, of sand size, is composed of quartz, but one or two feldspar and sedimentary rock fragments were noticed. A few rounded quartz grains were split in half during transport. The calcareous allochems, of sand size, are represented by a very few peloids and fossil fragments (Fig. 8A). In both, the calcite has been recrystallized. The borders of the peloids are mostly ill-defined because the peloids have become more or less completely incorporated in the cement, showing the same crystallographic orientation as the latter (Fig. 8B). The cleavage lines of the sparry cement continue in some cases into the calcareous grains. To a varying extent, the non-calcareous allochems are represented by phosphorite intraclasts of sand and pebble-size up to $20 \mathrm{~mm}$ or so.

The packing of the framework and the crystal size of the sparry cement vary widely. One pore space is occupied by more than one calcite crystal or several detrital grains are embedded in one single poikilitic calcite crystal (Fig. 8C). Dusty inclusions in the sparry cement appear to be relics of replaced micritic and granular material, now included in the cement. Several quartz grains show corroded and embayed edges (Fig. 8D). Tiny quartz-cemented patches were noticed within the calcitic sandstone. Pyrite, in amounts of less than $1 \%$, is locally present as small patches or dust.

\section{Calcitic siliceous submature glauconitic quartzarenite}

The rocks of this lithology are hard and compact, although intercalations of thin clayey layers cause an apparent friability. The colour varies from light to 


\begin{tabular}{|c|c|c|c|c|c|c|c|c|c|c|c|c|c|c|c|c|}
\hline \multirow[b]{2}{*}{ Samples } & \multirow[b]{2}{*}{ 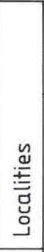 } & \multicolumn{3}{|c|}{\begin{tabular}{|c|} 
Mean of samples \\
Mz
\end{tabular}} & \multicolumn{3}{|c|}{$\begin{array}{c}\text { Sorting of samples } \\
\bar{\sigma}_{\varnothing}\end{array}$} & \multicolumn{2}{|c|}{$\begin{array}{c}\text { Mean of } \\
\text { roundness } \\
\text { Me }\end{array}$} & \multicolumn{4}{|c|}{$\begin{array}{c}\text { Sorting of roundness } \\
\sigma_{e}\end{array}$} & \multicolumn{2}{|c|}{ Fraction $<1 \varnothing$} & \multirow[b]{2}{*}{ 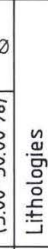 } \\
\hline & & 离 & 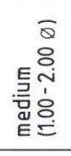 & 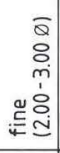 & 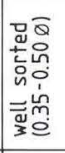 & 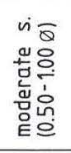 & 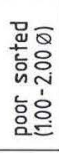 & 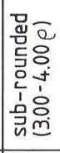 & 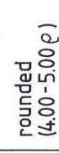 & 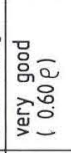 & 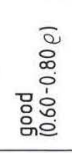 & 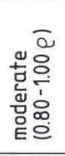 & ஓे & $\begin{array}{l}\overline{0} \\
8 \\
\circ \\
1 \\
1 \\
\vdots \\
0 \\
0\end{array}$ & 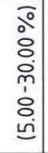 & \\
\hline$B o-A-13 b$ & 2 & & $x$ & & & $x$ & & & $x$ & & $x$ & & & & $x$ & 2 \\
\hline$B o-D-6 b$ & 2 & & $x$ & & & $x$ & & & $x$ & & $x$ & & & & & 2 \\
\hline Bo-F-1b & 3 & & $x$ & & & $x$ & & $x$ & & $x$ & & & & & & 2 \\
\hline Bo-G-3 & 3 & & $x$ & & & $x$ & & & $x$ & & $x$ & & & $x$ & & 2 \\
\hline Bo-E-2 & 3 & & & $x$ & & & $x$ & & $x$ & $x$ & & & & & & 3 \\
\hline Bo-F-8 & 3 & & $x$ & & & $x$ & & & $x$ & & $x$ & & & & & 3 \\
\hline$B o-F-1 d$ & 3 & & $x$ & & & $x$ & & & $x$ & & $x$ & & & & & 3 \\
\hline$B o-A-11$ & 2 & & $x$ & & & $x$ & & & $x$ & & $x$ & & & $x$ & & 4 \\
\hline Bo-D-11 & 2 & $x$ & & & & & $x$ & & $x$ & & $x$ & & & & $x$ & 4 \\
\hline Bo- $F-7$ & 3 & & $x$ & & & $x$ & & & $x$ & & $x$ & & & $x$ & & 4 \\
\hline$B o-F-1 a$ & 3 & & $x$ & & & $x$ & & & $x$ & & & $x$ & & & & 4 \\
\hline Bo-F-15 & 3 & $x$ & & & & $x$ & & & $x$ & & $x$ & & & $x$ & & 4 \\
\hline Bo-G-11 & 3 & & $x$ & & & $x$ & & & $x$ & & $x$ & & & & & 4 \\
\hline$B 0-F-12$ & 3 & $x$ & & & & $x$ & & & $x$ & & $x$ & & & $x$ & & 4 \\
\hline Bo-F-14 & 3 & & $x$ & & & $x$ & & $x$ & & $x$ & & & & $x$ & & 4 \\
\hline Bo-A-9 & 1 & $x$ & & & & $x$ & & & $x$ & & & $x$ & & $x$ & & 4 \\
\hline Bo-A-1 & 1 & $x$ & & & & $x$ & & $x$ & & $x$ & & & & $x$ & & 4 \\
\hline Bo-A-2 & 1 & $x$ & & & & $x$ & & & $x$ & & & $x$ & & & & 4 \\
\hline$B o-A-3$ & 1 & $x$ & & & $x$ & & & $x$ & & & $x$ & & & & & 4 \\
\hline$B o-A-4$ & 1 & $x$ & & & & $x$ & & & $x$ & & & $x$ & & $x$ & & 4 \\
\hline Bo-A- 5 & 1 & $x$ & & & & $x$ & & & $x$ & & & $x$ & & & & 4 \\
\hline Bo-A- 6 & 1 & $x$ & & & & $x$ & & $x$ & & & & & $x$ & $x$ & & 4 \\
\hline
\end{tabular}

Table II. Textural parameters of the sandstone lithologies. Lithology No. 2: calcitic submature quartzarenite; lithology No. 3: calcitic siliceous submature glauconitic quartzarenite; lithology No. 4: siliceous submature quartzarenite.

greenish-grey (N7 to 5G 6/1) and low-angle cross strata and horizontal lamination is present. The clayey layers and the glauconite disappear upwards, changing the rocks gradually into the calcitic sandstone. Texturally, the rocks are fine to medium $\left(\mathrm{M}_{\mathrm{z}}: 3,00\right.$ to $\left.1,00 \varnothing\right)$, poorly to moderately sorted $\left(\sigma_{\varnothing}: 0,50\right.$ to $\left.2,00 \varnothing\right)$ sandstones (Table II). They are rounded $\left(\mathrm{M}_{\varrho}: 4,00\right.$ to $5,00_{\mathrm{Q}}$ ) and the roundness standard deviation ranges from very-good to good roundness sorting $\left(\sigma_{\mathrm{Q}}: 0,60\right.$ to $\left.0,80_{\mathrm{Q}}\right)$. 
The rocks, composed chiefly of terrigenous grains with small proportions of glauconite grains and even fewer calcareous allochems (Table I) are cemented either by quartz or by sparry calcite. Only small spots of glauconite cement were observed. Both sand and silt-sized quartz and sand-sized glauconite are embedded in the clayey laminae. Here, slight silicification of the clay occurs. There is a tendency for both types of cement to be segregated in vague parallel bands. The quartz-dominated bands progressively disappearing upwards throughout the lithology.

The terrigenous detritus is composed mainly of quartz grains but one or two feldspar grains and sedimentary rock fragments were observed. Very fine sand is locally present, being more abundant where there is quartz cement, in which case it is disposed as a 'matrix' between the coarse sand grains. Here, the packing is very tight and sutured contacts are frequent (Fig. 8E).

Very few peloids and obliterated calcareous fossil fragments are the calcareous allochems present in this lithology. They have been recrystallized and are in many cases difficult to recognize because they have been absorbed into the cement, both showing the same crystallographical orientation (Fig. 8F). The chambers of the calcareous chambered shells are empty or have been filled with calcite or glauconite which also partially replaced the shells (Fig. $8 \mathrm{G})$.

Rounded glauconite grains, in varying amounts of up to $10 \%$ of the rock, occur scattered throughout, as well as concentrated at certain levels. In some cases, the glauconite has been partially squeezed between the surrounding terrigenous detritus. Calcite replaces the glauconite in the fossils (Fig. $8 \mathrm{H}$ ) and in the glauconite grains (Fig. 9A), leaving in the latter case irregular glauconite masses within the calcite cement. Detrital quartz grains show etched and embayed edges which indicate solution and replacement. Removal of quartz by calcite replacement is considered to be extremely important in modifying the original percent composition of the detritus deposited (Dapples 1967). Calcite replacement of detrital quartz is in some instances so advanced that only a small irregular quartz piece remains as an inclusion within the replacing mineral (Fig. 9B). In certain cases, a speck of either quartz or glauconite is left within the calcite grains, suggesting that at least some of them may be a result of a complete replacement of either quartz or glauconite by calcite.

Where sparry calcite cement predominates, the detrital grains do not always come into contact with each other. The crystals of the neomorphic spar vary widely in size, but large poikilitic crystals with well-developed cleavage lines are common. As has been noticed in the calcareous sandstone, there are also, in this lithology, dusty inclusions in the sparry cement which suggests inclusions of remnant grain material in the cement (Fig. 9C). 
Where quartz cement is present it is in optical continuity with the detrital grains. In certain cases, megaquartz crystals of $20-80 \mu \mathrm{m}$ seem to have developed upon the syntaxial quartz overgrowth (Fig. 9D). Considering the latter and the observed slight silicification in the clayey layers, the reports of Dapples (1972) on chertification of matrix in sandstones, as well as the occurrence of chert being crystallized on earlier overgrowth of monocrystalline quartz, are of particular interest in this connection.

\section{Siliceous submature quartzarenite}

The rocks of this lithology vary widely in proportion and kind of both cement and framework (Table I), but all have in common the presence of silica cement either in the form of megaquartz or as chert. Calcite and phosphate cement are locally present in smaller quantites, although an upward decrease in the percentage of silica cement is accompanied by an increase in porosity and occurrence of phosphate cement as well as the incidence of varying amounts of clayey, and to a lesser degree, silty matrix. Variable and irregular distribution of the cements results in a variation in colour, porosity, hardness and cohesion of the rocks. Thus, macroscopically, the rocks range from massive and hard, showing a grey colour (N7 to N4) to partially friable, limonite-stained, in cases with mottled appearance and a light to moderate brown colour (5YR 5/6 to 5YR 4/4). According to Pettijohn et al. (1972), limonite is the field name used for a mixture of göethite and lepidocrocite.

This lithology is represented by moderately sorted $\left(\sigma_{I}=0,50\right.$ to $\left.1,00 \varnothing\right)$, coarse and medium sandstones $\left(\mathrm{M}_{\mathrm{z}}=0\right.$ to $\left.2,00 \varnothing\right)$, (table II). Only one sample is well-sorted $\left(\sigma_{I}=0,35\right.$ to $\left.0,50 \varnothing\right)$. The mean roundness ranges from sub-rounded to well-rounded $\left(\mathrm{M}_{\mathrm{e}}=3,00\right.$ to $\left.5,00_{\mathrm{e}}\right)$ and the roundness sorting of most of the samples ranges from good to moderate $\left(\sigma_{\mathrm{e}}=0,60\right.$ to $\left.1,00_{\mathrm{e}}\right)$ although one or two samples have either good $\left(\sigma_{\mathrm{e}}<0,60_{\mathrm{e}}\right)$ or poor $\left(\sigma_{\mathrm{e}}=1,00\right.$ to $1,20_{\mathrm{e}}$ ) roundness sorting. Most samples of this lithology are slightly conglomeratic (gravel \% between 0,01 and 5,00), but in one sample the gravel content is larger than $5 \%$, therefore being classified as conglomeratic sandstone.

The majority of the framework is represented by terrigenous quartz, but allochems are generally present and locally abundant. The terrigenous detritus is composed of mainly quartz grains, plus sparse quantites of feldspar, sedimentary rock fragments and heavy minerals. A few quartz grains with double quartz overgrowth were noticed (Fig. 9E).

The allochems are represented by peloids, chert (Fig. 9F) and phosphate grains, fossils and phosphorite intraclasts. The latter, of sand and gravel-size 
with variable shapes, are found throughout the lithology, whereas the other allochems occur only locally, mostly in the layers where chert cement is well-developed. There, the bioturbation has been intense and destroyed the sedimentary structures; thus the rocks are massive.

The fossils are composed either of calcite or phosphate (Fig. 9G) or they have been glauconitized or chertified (Fig. 9H). Most fossils are chambered. The chamber walls, in many cases, have been partially or totally destroyed and the remaining voids are now empty or filled to a varying degree with the same mineral which forms the shell (Fig. 10A), or with a different one (Fig. 10B). Subsequently, diagenetical replacements occurred in either the shells or their filling, in some cases both. In certain instances, where the chambers have been left empty, the interior walls show a black coating, probably remains of organic matter. Thus the fossils present in this sandstone have been obliterated to a varying degree, due to partial dissolution of the shell structures as well as to the different replacements that they have undergone during diagenesis. In some cases, when glauconitized fossils have their chambers filled by glauconite, different degrees of chertification of the glauconite were observed both in the shells and in the chambers (Fig. 10C).

Silica cement is in the form of either syntaxial quartz overgrowth or drusoid megaquartz crystals generally $20-80 \mu \mathrm{m}$ in size or chert (cf. Folk 1974; Folk \& Weaver 1952). There are samples in which all six varieties of cement are present while in others the only cement is syntaxial quartz over-

Fig. 9. Calcitic siliceous submature glauconitic quartzarenite. A. Sample: Bo-E-2, locality 3, crossed nicols, $\times 95$; glauconite grain partially replaced by calcite. B. Sample: Bo-E-2, locality 3 , crossed nicols, $\times 95$; detrital quartz grains replaced by calcite. Note the anomalous outline of the replaced quartz. C. Sample: Bo-F-1d, locality 3 , crossed nicols, $\times 15$; note the remnant of grain material that has been included in the cement which has developed large poikilitic crystals. D. Sample: Bo-E-2, locality 3 , crossed nicols, $\times 95$; small megaquartz crystals seem to have developed upon the syntaxial quartz overgrowth. Siliceous submature quartzarenite. E. Sample: Bo-A-1, locality 1 , crossed nicols, $\times 38$; detrital quartz grains cemented by secondary quartz overgrowth in optical continuity with the detrital grains. Note the quartz grain with double quartz overgrowth at the centre of the picture. F. Sample: Bo-D-11. locality 2 , crossed nicols, $x$ 38; chert and phosphorite grains, obliterated phosphatic fossil fragments and detrital quartz. Cement is chiefly chert and to a lesser degree megaquartz which also fills fossil chambers. Small remains of phosphatic cement within the chert in the upper part of the picture. G. Sample: Bo-D-11, locality 2, plane polarized light, $\times 38$; quartz sand and phosphatic fossil debris. Chambers in the fossil fragments are partially filled by calcite which has been slightly phosphatized. Later, chlorite in part replaced phosphate and calcite. The voids due to partial dissolution of calcite within the fossil fragment at the lower left have been partially filled by megaquartz. The cement is chert. Small patches of calcite cement remaining at the centre both left and right of the picture are surrounded by megaquartz. H. Sample: Bo-A-11, locality 2 , crossed nicols, $\times 38$; chertified obliterated fossil fragment. One chamber wall has been partially destroyed. The chambers are empty. 

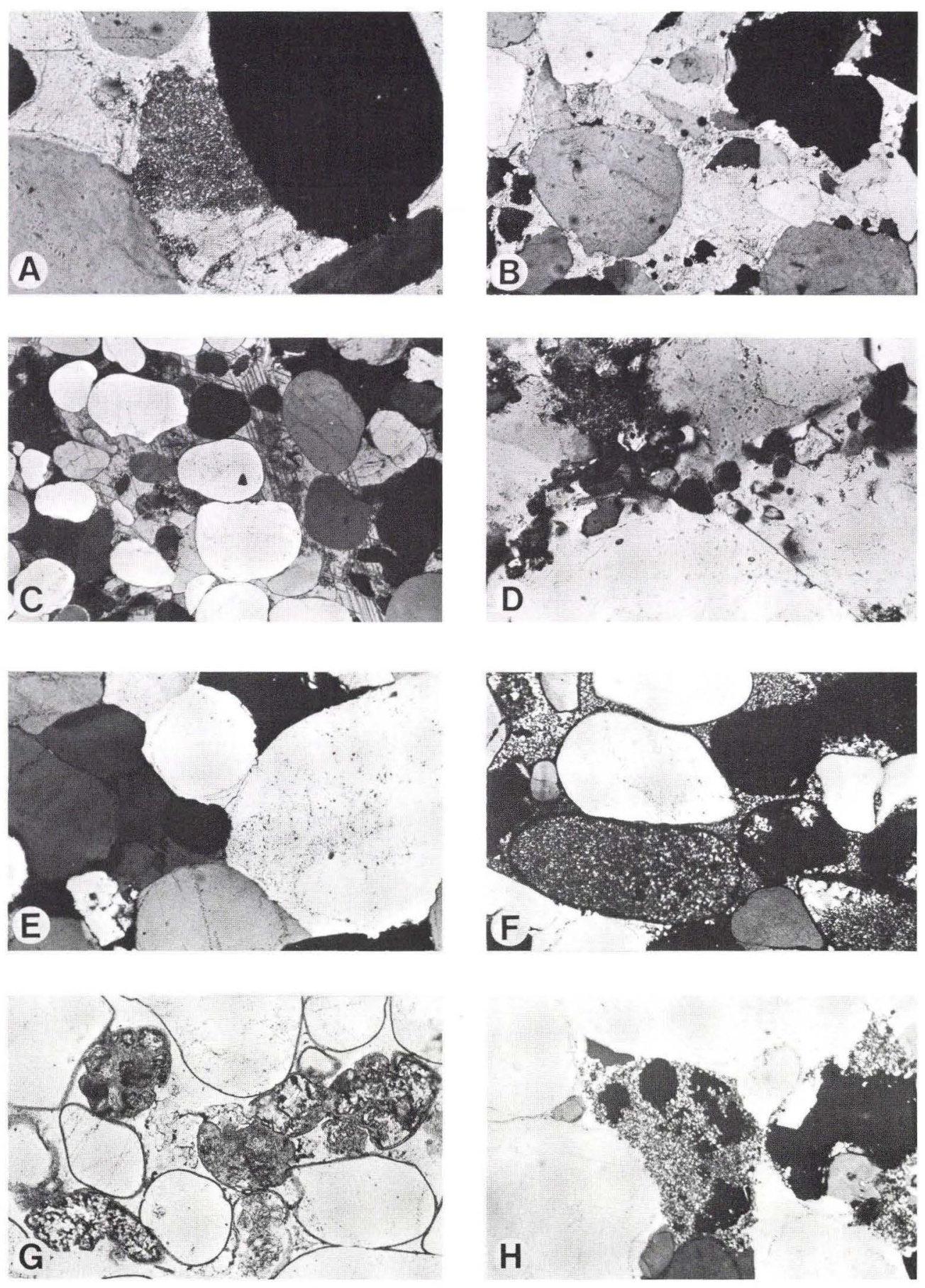
growth. The latter is irregularly distributed, thus there are pores which remain empty while others are partially or totally filled by the cement. In cases, this cement shows well-developed euhedral crystal faces.

Chert, composed of equant grains of microcrystalline quartz $(20 \mu \mathrm{m})$, is locally developed in this lithology, either spread throughout the sandstone bed or forming irregular lumps within the layer. Where chert cement occurs, unconsolidated sand is generally found close by. Generally, chert is found as a replacement for another mineral in both the allochems (Fig. 10D) and the cements. Occasionally, slight recrystallization of the clayey matrix also caused chert formation. In these cases, some quartz grains show serrated contacts. On the other hand, the megaquartz crystals are found filling, with drusoid habit, either primary cavities such as those in the interior of the fossils or secondary cavities such as those caused by partial calcite dissolution (Fig. 10E). Chert and megaquartz crystals of about $30 \mu \mathrm{m}$ or so also seem to have developed upon the syntaxial quartz overgrowth in this lithology (Fig. 10F) (cf. Dapples 1972). The latter case was also noticed in the previously described glauconitic sandstone.

Small scattered patches of sparry calcite are in contact with the detrital quartz or with its syntaxial quartz overgrowth, in cases replacing both. Slight

Fig. 10. Siliceous submature quartzarenite. A. Sample: Bo-F-15, locality 3 , crossed nicols, $\times$ 38; at the centre of the picture an obliterated calcareous fossil with chambers filled by calcite. The latter shows one single optical orientation. The fossil shell is chertified in places. Chlorite later partially replaced chert and calcite. Cement is chert and syntaxial quartz overgrowth. Spot of calcite and phosphate cement remain within the chert. B. Sample: Bo-D-11, locality 2, crossed nicols, $\times 38$; obliterated phosphatic fossil fragments filled by calcite that later was partially phosphatized. The black spot within the fossil fragment at the centre right is made up of voids due to partial dissolution of calcite. Cement is small crystal of megaquartz and syntaxial quartz overgrowth. C. Sample : Bo-G-15b, locality 3, crossed nicols, $\times 38$; glauconitized fossil fragments secondarily chertified. Black spots are pyrite. The cement is chert. D. Sample: Bo-D-11, locality 2, plane polarized light, $\times 38$; detrital quartz grains, phosphorite intraclast, phosphatic fossil fragments and one phosphate grain partially chertified. Chert partially replaces the phosphate as well in the fossil fragments. Chambers filled by magaquartz which also cements the framework. E. Sample: Bo-F-15, locality 3, crossed nicols, $\times 38$; syntaxial quartz overgrowth, chert, calcite and megaquartz growing with drusoid habit are the cements present. Note the euhedral crystal faces developed by the syntaxial quartz overgrowth. Megaquartz fills the voids caused by partial dissolution of the calcite cement. F. Sample: Bo-D-11, locality 2, crossed nicols, $\times 38$; note the small megaquartz crystals near the edge of the detrital quartz sand at the centre of the picture. They seem to have developed upon the syntaxial quartz overgrowth. G. Sample: Bo-F-15, locality 3 , crossed nicols, $\times 38$; at the centre of the picture, chert partially replaced the calcite of the peloid. The black spot in the peloid is pyrite. At the centre right, a spot of chert has developed upon the syntaxial quartz overgrowth. H. Sample: Bo-A-6, locality 1, crossed nicols, $\times 150$; authigenic rutile crystals protruding from an iron-rich mass within a pore space between detrital quartz grains. 

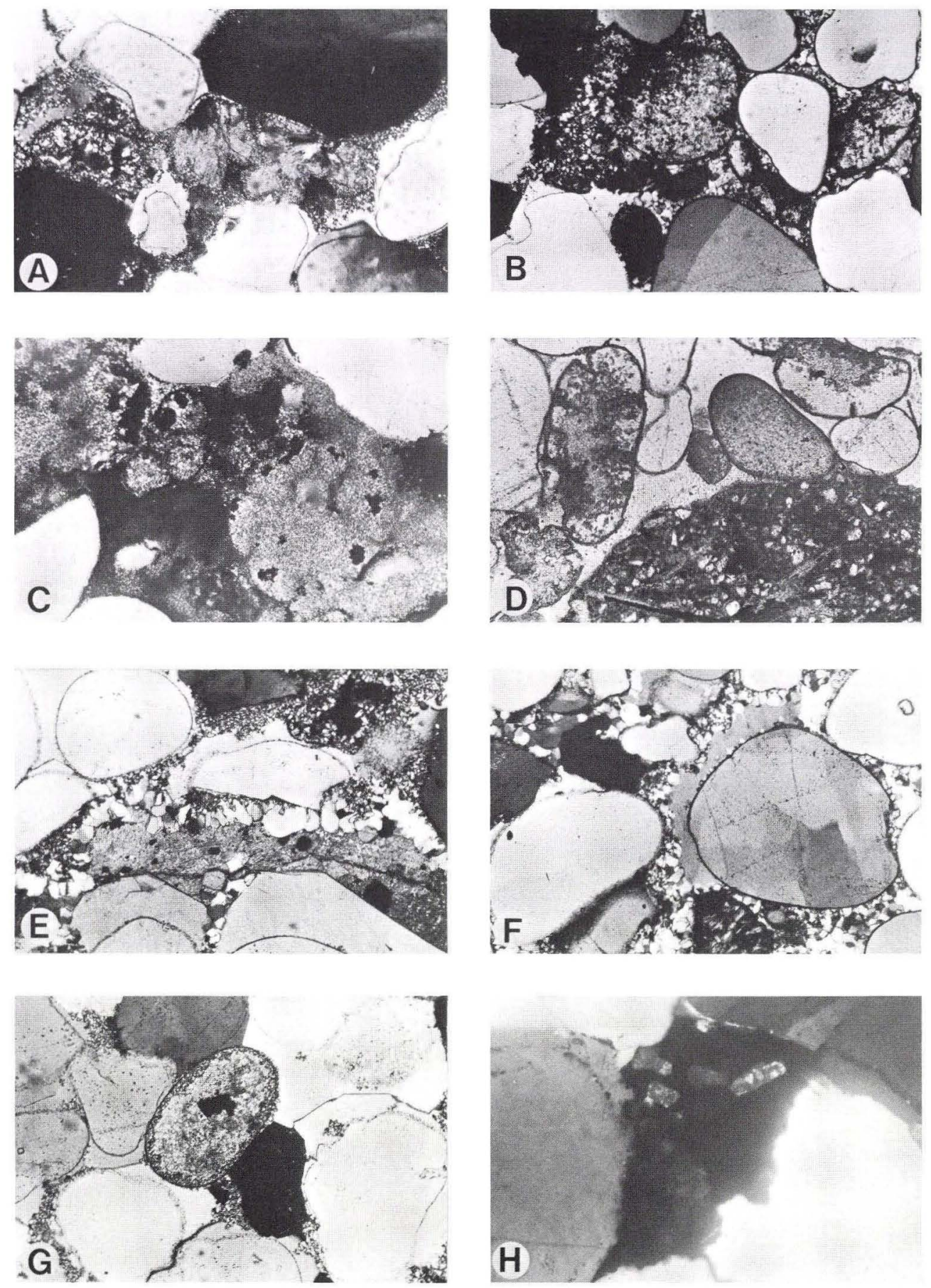
phosphatization and chertification of the calcite cement has been observed. Taking into account the above-described condition and the fact that small megaquartz crystals were found growing in secondary cavities caused by partial dissolution of the calcite cement, it seems that syntaxial quartz overgrowth is the first deposited cement and calcite the second, whereas megaquartz crystals and chert were developed during a second silicification stage. Phosphate cement, irregularly distributed and generally in low amounts, has been differentially chertified as there are areas without any sign of silicification. Where phosphate cement is present, it is in contact with the detrital quartz or its syntaxial quartz overgrowth. When the phoshpate has been chertified, often a phosphatic halo remains between the chert and the detrital quartz or its syntaxial overgrowth.

The diagenetical history of this sandstone is very complex and not yet totally clear. Replacement of (a) calcite by phosphate or chert (Fig. 10G), (b) phosphate by chert and (c) glauconite by chert has occurred to a varying degree, both in the allochems and in the orthochemical components. In certain instances, more than one of the above-named replacements have taken place within a single fragment. Furthermore, authigenic chlorite and pyrite occur, attaching frameworks and cements, affecting the latter mineral, also the chlorite. Authigenic rutile protruding from an iron-rich mass has been observed (Fig. 10H). These rutile crystals show the same optical characters as described by Teodorovich (1961) for authigenic rutile produced by decomposition of ilmenite. The constant relationship between the rutile and the iron-rich mass, together with the optical characters of these rutile crystals, suggests that the latter are authigenically formed by alteration of ilmenite. 


\section{Discussion}

The Rispebjerg Sandstone on Bornholm, Denmark, is composed of calcitic, glauconitic and siliceous sandstone beds with intercalations of phosphorite layers. Fossil fragments are locally present in all lithologies; they are usually scarce but are quite common in some instances.

The phosphorite containing varying amounts of terrigenous and calcareous and non-calcareous allochems is micritic in texture. Bioturbation has been intense during deposition of the phosphorite layers, as most sedimentary structures have been destroyed (cf. Reineck \& Singh 1973).

The chemical composition and crystallographic structures of the different components of the apatite group have been extensively discussed in the literature, e.g. by Mc Connell (1938, 1952), Ames (1959) and Gulbrandsen $(1966,1969)$. Different mechanisms have been proposed to explain the genesis of the phosphorites. Two main lines were followed: (a) direct inorganic chemical precipitation from saturated phosphorous solutions (Kazakov 1937; Diets et al. 1942; McKelvey et al. 1953; Gulbrandsen 1969) and (b) replacement processes from previously deposited carbonate sediment (e.g. Ames 1959; Pevear 1966, 1967). Biochemical influence in the formation of phosphorite was discussed by Cayeux (1936), Bushinsky (1964) and McConnell (1965).

Ames (1959), concluded that carbonate-apatite cannot be formed by direct inorganic precipitation from solution and that apatite replacement of carbonates is the most probable mode of formation of large marine phosphorite deposits. There are many reports of phosphatization by replacement of carbonate structures (e.g. Bushinsky 1935, 1964; Hamilton \& Rex 1959; Pevear 1966; d'Anglejan 1967, 1968; Rapson-McGugan 1970; Marlowe 1971).

Fairbridge (1967:72) considers that, as the abundance of phosphorous is rather low in sea water (about $0,07 \mathrm{mg} / \mathrm{l}$ ), the limiting factor in phosphatization is the local concentration by organic metabolism. He discusses the process of phosphatization of marine carbonate sediments (often in the form of aragonite, which is particularly soluble in fresh water of only slightly reduced $\mathrm{pH}: 6,5-7,5)$ on atolls and on shallow shelves where favourable conditions for accumulation of organic phosphate exist. He considers that if an epidi- 
agenetic stage is arrived at as a result of a sudden sea water lowering, phosphorous mobilization due to rain water leaching into freshly formed limestone would promote formation of phosphate minerals.

The good roundness of most of the quartz sand grains embedded in the micritic phosphorite implicates high enerty conditions that should have winnowed the finer particles. Therefore, the roundness of the sand grains must have been inherited from a previous sedimentary environment.

During the deposition of the sediment, bioturbation as well as local and penecontemporaneous erosion and redeposition, together with a variable influx of terrigenous debris, produced a mixture of sediments of the same general character but with slight lithological differences. The resulting rocks are massive or spotted. Only in a few cases was horizontal lamination recorded. Horizontal lamination may reflect deposition of sand from suspension during storms (Reineck \& Singh 1973), or upper flow regime conditions (Matthews 1974).

In many cases, both allochems and terrigenous components float in the phosphoritic matrix and replacement of originally calcareous matter by carbonate-apatite has taken place. This suggests that the original sediment was microcrystalline calcite ooze in which terrigenous and allochemical components were deposited, and which was later replaced by phosphorous from sea water (cf. Ames 1959). The replacement has been differential, as many isolated carbonate allochems show no sign of replacement. The effects of calcite grain size on the relative rate of replacement by phosphate (increase in surface area will promote replacement) were discussed by Bushinsky (1935), Ames (1959) and d'Anglejan (1968). The differential replacement of the calcareous components might be due to difference in both crystal size and overall permeability.

As previously noted, the phosphorite is found in different stratigraphical positions throughout the Rispebjerg Sandstone, and the shift from both the calcitic submature quartzarenite and the siliceous submature quartzarenite into the phosphorite is gradual. Furthermore, the shape and roundness of the phosphorite intraclasts generally suggests both short transport and a weak consolidation of the sediment at the time of the redeposition. Thus it seems that most of the replacement by carbonate-apatite was penecontemporaneous with the sedimentation and took place at or near the sediment surfaces. Similar conditions were described by d'Anglejan (1968) for carbonate sediments of a core from the eastern Pacific.

Moreover, the presence of these phosphorite intraclasts and their genesis, discussed above, suggests that the phosphatization process in the Rispebjerg Sandstone must have occurred under sea water, at the contact sea water-sediment surface, and not in the manner proposed by Fairbridge (1967), i.e. 
during an epidiagenetic stage by leaching of organic phosphate under rain water.

Sediment with a composition such as this which characterizes the phosphorite lithology is formed, for example, where a sandy barrier lies offshore from a mud lagoon. Storm blow the sand back into the lagoon and sand and mud are then mixed by bioturbation (cf. Folk 1962, 1974). When the rate of bioturbation is less than that of the drifting sand, layers of pure sand remain unmixed and horizontal lamination is preserved (cf. Reineck \& Singh 1973). It is probable that these sedimentary processes, penecontemporaneously followed by phosphatization, are the main events responsible for the formation of the phosphorite layers present in the Rispebjerg Sandstone.

The areal distribution of the phosphorite lithology of the Rispebjerg Sandstone, also present in the south of Scania, Sweden, indicates that the phosphatization process was not only of local dimensions but more of regional proportions.

Sediments deposited in beaches, that is, in loci of intense abrasion and sorting where energy is constantly being expended on the grains, are characteristically supermature (Folk 1974). Considering the mean roundness $\left(\mathrm{M}_{\mathrm{e}}\right)$ of the sand-size particles of the sandstone lithologies ( $\mathrm{o}$ over 3,00) the rock should be classed as supermature. However, owing to the fact that all but one specimen are not well-sorted $\left(\sigma_{\varnothing}\right.$ over $\left.0,50 \varnothing\right)$, they are classed as submature. Thus, according to the textural maturity of these sandstones they do not seem to represent beach sands. Because of the high roundness, it is a case of textural inversion and the roundness must have been inherited from older sediments. Furthermore, the presence of quartz grains with double quartz overgrowth and sedimentary rock fragments indicates that at least part of the sediment is derived from older sedimentary rocks. Considering the textural character of the sandstone lithologies and the circumstance that they are interstratified with (phosphatic) sediments, interpreted as of lagoonal origin, they may represent sediments deposited in a tidal complex on the landward side of a sandy barrier.

The presence of phosphorite intraclasts embedded in layers of the same or another lithology indicates penecontemporaneous erosion. The sandy level at the base of the uppermost phosphorite layer contains pebbles of phosphorite and of the underlying silicified sandstone. The presence of the latter indicates more profound local erosion of strata much lower stratigraphically within the Rispebjerg Sandstone, hence the existence of an intraformational unconformity. Considering the above-exposed and the fact that the different phosphorite layers are not always present everywhere, it seems that deposition of the Rispebjerg Sandstone was interrupted by penecontemporaneous erosion stages (Fig. 11). 
Where poikilitic calcite crystals are well-developed, the packing of the framework is generally loose. This seems to be due, at least in part, to volume expansion of the grain-supported framework by development of the large pseudospar crystals as a result of recrystallization of the micritic cement (cf. Dapples 1971). The presence of neomorphic spar, indicates the effects of fresh water influence that removes the $\mathrm{Mg}$ from the rocks and allows recrystallization of the micritic cement to pseudospar (Folk 1974a). According to Dapples (1972), corrosion of quartz and replacement by calcite is more common where introduction of calcite cement is important but is not accompanied by volume expansion. However, it is interesting to note that removal of quartz by calcite replacement has been in cases considerable in the studied sandstones, as in certain instances only a piece of the quartz grain remains as an inclusion in the sparry cement, and volume expansion, as a result of the development of large neomorphic crystals, seems to have occurred.

The fact that quartz and calcite are present together as cementing minerals in the sandstone lithologies indicates changes of the $\mathrm{pH}$ and temperature within the sediment (cf. Walker 1962). Glauconite found as cement between the frameworks and in the interior of the shells, replacing in some cases the latter, indicates a glauconitization stage prior to the calcification one, during which glauconite in the fossils and in the allochemical grains was replaced by calcite.

Chert grains, chert cement and chertified fossil fragments are locally found in the siliceous quartzarenite. There, well-rounded detrital quartz, now cemented by chert, show etched and embayed edges in certain instances. Dapples (1972) reported that chertification of matrix in sandstones is accompanied also by strong corrosion of monocrystalline quartz grains and a tendency for the neomorphed chert to weld to such irregular surfaces. However, as in many cases a phosphatic rim lies between the chert cement and the terrigenous quartz or its syntaxial quartz overgrowth, another mechanism than that described above must have caused this chemical corrosion. Corrosion of detrital quartz by phosphate was reported by Rapson-McGugan (1970). But, as previously noted, calcite seems to be the second deposited cement mineral. On the other hand, calcite replacing terrigenous and syntaxial quartz and phosphate replacing calcite occur.

Chert, formed by diagenetic alteration of sediment composed chiefly of biogenic silica (McBride \& Folk 1977; Folk \& McBride 1978), by replace-

Fig. 11. Schematic representation of the possible stages during the formation of the Rispebjerg Sandstone. Lithology No. 1: calcitic siliceous submature glauconite quartzarenite; Lithology No. 2: calcitic submature quartzarenite; Lithology No. 3: phosphorite; Lithology No. 4: siliceous submature quartzarenite. The symbols I, II and III in the phosphorite lithology refer to its different layers. For further explanation, see text. (N.B. Diagram not to scale). 

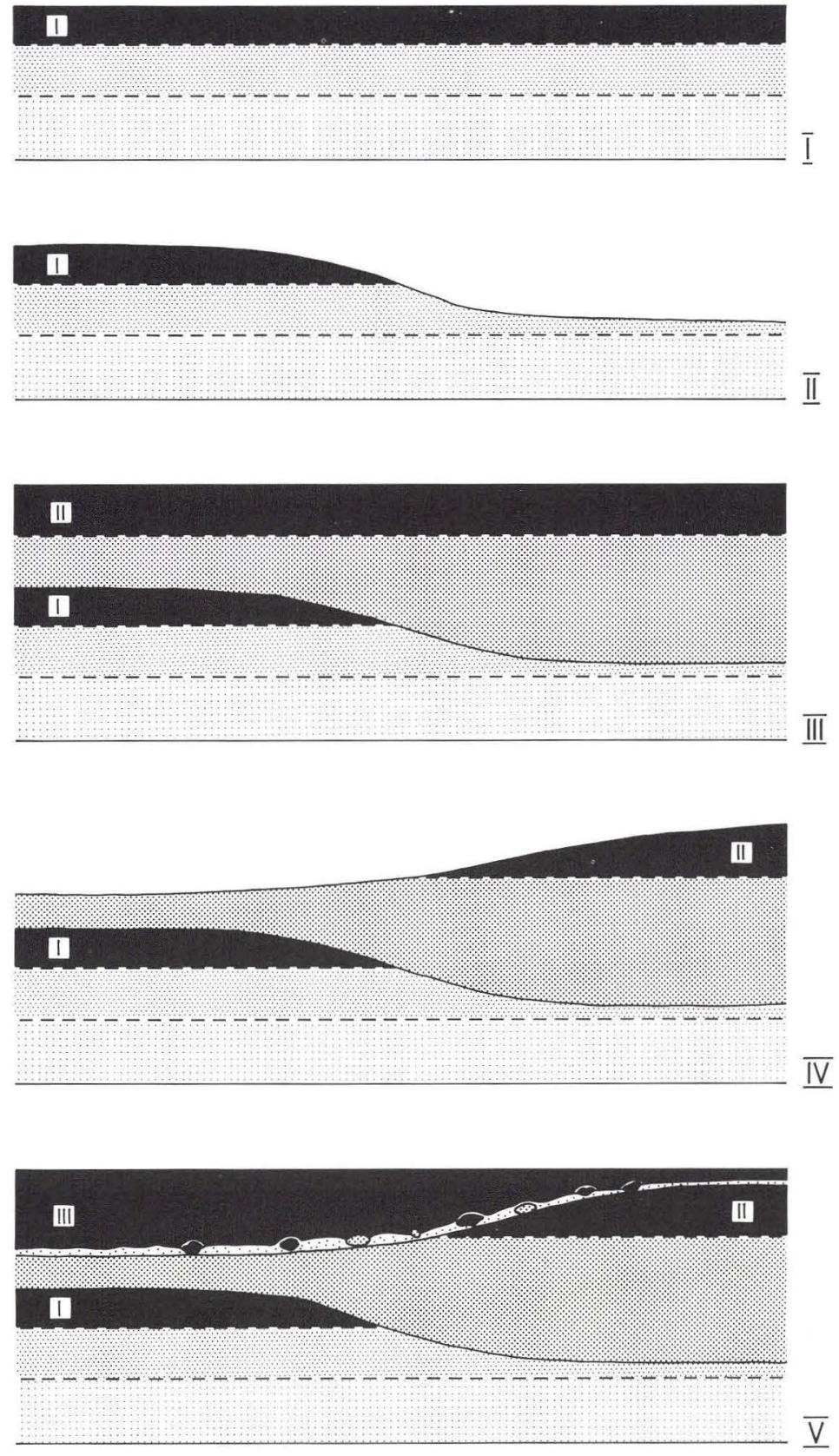

$\square 103$ 
ment of pelletal phosphorite (Rapson-McGugan 1970), as a product of recrystallization and neoformation of new clay minerals from the detrital mixture of clay minerals (Dapples 1972), by alteration of volcanic ash on the sea floor (Goldstein 1959) or by diagenetical replacement of calcite (Walker 1962) were some of the mechanisms proposed, amongst others, to explain the origin of chert. Furthermore, Dapples (1972) reported examples which indicate that chert was crystallized upon earlier overgrowth of monocrystalline quartz. Replacement of calcite, phosphate and glauconite by chert occurs both in the allochems and in the cement. Therefore it may be possible that calcite was the former mineral cement which made the corrosion of the detrital quartz grains, later partially phosphatized and then, in turn, both calcite and phosphate were secondarily replaced by chert during the second stage of silicification. Because of the above, it may also be possible that the chert grains locally present in this sandstone are the result of complete replacement of both calcite or phosphate grains by chert. However, cases were noticed in which chert, in minor proportions, seems to have been crystallized upon earlier overgrowth of monocrystalline quartz, and also to have formed as a product of recrystallization of clayey matrix. In the latter case, chlorite is in certain instances interlocked with the chert. 


\section{Conclusions}

On the basis of the foregoing evidence and arguments, the main events which seem to have occurred in the formation of the Rispebjerg Sandstone, regardless of their paragenetic sequence, are as follows:

a) Calcareous mud was deposited in a barred lagoon in which storms blew sand back from the barrier. Sand was subsequently mixed with mud by bioturbation. Penecontemporaneously with deposition of this sediment, phosphatization by replacement of calcite by phosphorous from sea water, according to the experimental conclusions of Ames (1959), is, in this paper, the favoured origin for the phosphorite layers present in the Rispebjerg Sandstone.

b) The submature sandstone layers interstratified with the phosphorite layers may represent sediments deposited in the tidal complex on the lee side of the sandy barrier.

c) The good roundness of the quartz grains found in the different lithologies is interpreted as inherited from older sediments.

d) Deposition of the Rispebjerg Sandstone seems to have been interrupted by penecontemporaneous erosion stages, one of which caused formation of an intraformational unconformity.

e) The intercalations of phosphorite layers in the sandy deposit may reflect fluctuations of the sea level which caused shifts of the shoreline of the lagoon-barrier complex.

Bioturbation, penecontemporaneous erosion stages and several diagenetical replacements, such as phosphatization, glauconitization, chertification, calcification, chloritization and pyritization occurred in the Rispebjerg Sandstone. The replacement processes took place during and after the deposition of the Rispebjerg Sandstone. The combination of these sedimentary processes contributed to obscuring the original nature of the sediment and accomplished the reconstruction of the environment of sedimentation.

Acknowledgements. I am indebted to Prof. G. Regnéll for his valuable assistance and criticism. I would also like to express my gratitude to Prof. G. Larsen for his kind interest in, and construc- 
tive discussion of, this work. Special thanks are due to Prof. R. Folk for his kindness in answering questions connected with this investigation. I am also grateful to Jan Bergström for his advice and criticism of the manuscript. Thanks are due to Tamara Nutting for correction of the English. 


\section{References}

Ahlberg, P. \& Bergström, J., 1978: Lower Cambrian Ptychopariid trilobites from Scandinavia. Sveriges Geologiska Undersökning Ca, 49, 1-41.

Ames, L. L. jr., 1959: The genesis of carbonate apatites. Economic Geology 54, 829-840.

d'Anglejan, B. F., 1967: Origin of marine phosphorites off Baja California, Mexico. Marine Geology 5, 15-44.

d'Anglejan, B. F., 1968: Phosphate deagenesis of carbonate sediments as a mode of in situ formation of marine phosphorites: Observations in a core from the eastern Pacific. Canadian Journal of Sciences 5, 81-87.

Bathurst, R. G. C., 1971: Carbonate sediment and their diagenesis. In: Developments in Sedimentology 12, 620 pp. Elsevier, Amsterdam.

Beales, F., 1971: Cementation in ancient pelletted limestones. In: O. P. Bricker (ed.): Carbonate cements. The Johns Hopkins University, Studies in Geology No 19, 216-224.

Bergström, J., 1970: Rusophycus as an indication of early Cambrian age. In: J. P. Crimes \& J. C. Harper, (eds.): Trace fossils. Geological Journal, Spec. Iss., 3, 35-42.

Bushinsky, G. I., 1935: Structure and origin of phosphorites of the U.S.S.R. Journal of Sedimentary Petrology 5, 81-92.

Bushinsky, G. I., 1964: On shallow-water origin of phosphorite sediments. In: L.M.J.U. van Straaten (ed.): Developments in Sedimentology 1, 67-70. Elsevier, Amsterdam.

Cayeux, L., 1936: Phosphates sedimentaires et bactéries. Compte Rendu 203, 1198-1200.

Dapples, E., 1967: Diagenesis of sandstones. In: G. Larsen \& G. V. Chilingar (eds.): Diagenesis in Sediments, Developments in Sedimentology 8, 91-125.

Dapples, E., 1971: Calssification of carbonate cements in quartzose sandstones. In: O. P. Bricker (ed.): Carbonate cements. The Johns Hopkins University, Studies in Geology No 19, 308-311.

Dapples, E., 1972: Some concepts of cementation and lithification of sandstones. American Association of Petroleum Geologists Bulletin 56(1), 3-25.

Deeke, W., 1897: Die phosphoritführenden Schichten Bornholms. Mittheilungen des naturwissenschaftlichen Vereines für Neu-Vorpommern und Rügen, Jhrg. 29, 1-15.

Deeke, W., 1899: Geologischer Führer durch Bornholm. Sammlung geologischer Führer III, Berlin, 1-68.

Fairbridge, R. W., 1967: Phases of Diagenesis and Authigenisis. In: G. Larsen \& G. V. Chilingar (eds.): Diagenesis in Sediments, Developments in Sedimentology 8, 19-89.

Folk, R. L., 1954: The distinction between grain size and mineral composition in sedimentary-rock nomenclature. The Journal of Geology 62, 344-359.

Folk, R. L., 1955: Student operator error in determination of roundness, sphericity and size. Journal of Sedimentary Petrology 25(4), 297-301.

Folk, R. L., 1959: Practical petrographic classification of limestones. American Association of Petroleum Geologists Bulletin 43, 1-38. 
Folk, R. L., 1962: Spectral subdivision of limestone types. In: W. E. Hau (ed.): American Association of Petroleum Geologists Memory 1, 62-84.

Folk, R. L., 1965: Some aspects of recrystallization in ancient limestones. In: L. C. Pray \& R. C. Murray (eds.): Dolomitization and Limestone Diagenisis. Society Economic Palaeontologists and Mineralogists, Spec. publ. No 13, 14-48.

Folk, R. L, 1974a: The natural history of crystalline calcium carbonate: Effect of magnesium content and salinity. Journal of Sedimentary Petrology 44(1), 40-53.

Folk, R. L., 1974b: Petrology of sedimentary rocks. 182 pp. Hemphill Publishing Co., Austin.

Folk, R. L. \& McBride, E. F., 1978: Radiolarites and their relation to subjacent »oceanic crust « in Liguria, Italy. Journal of Sedimentary Petrology 27(4), 1069-1102.

Folk, R. L., Andrews, P. B. \& Lewis, D. W., 1970: detrital sedimentary rock classification and nomenclature for use in New Zealand. New Zealand Journal of Geology and Geophysics 13, 937-968.

Folk, R. L. \& Ward, W. C., 1957: Brazos River Bar: a study in the significance of grain sized parameters. Journal of Sedimentary Petrology 27, 3-26.

Folk, R. L. \& Weaver, C. E., 1952: A study of the texture and composition of chert. American Journal of Science 250, 498-510.

Friedman, G. M., 1958: Determination of sieve-size distribution from thin-section data for sedimentary petrological studies. The Journal of Geology 66, 394-416.

Glagolev, A. A., 1933: On geometrical methods of quantitative mineralogical analysis of rocks. Trudy Inst. Prikladno i Mineralogii, No 59; transl. by J. B. Sykes. Atomic Energy Rsch. Establishment Lib. Trans. 567, 1955, 1-51.

Glagolev, A. A., 1934: Quantitative analysis with the microscope by the »point method. Engineering and Mining Journal 135(9), 399-400.

Goldstein, A. (jr.), 1959: Cherts and novaculities of Ouachita facies. Society Economic Palaeontologists and Mineralogists, Spec. publ. No 7, 135-149.

Grönwall, K. A., 1899: Bemaerkninger om de sedimentaere Dannelser paa Bornholm og deres tektoniske Forhold. Danmarks Geologiska Undersøgelse 2(10), 1-48.

Grönwall, K. A., 1902a: Studier öfver Skandinaviens Paradoxideslag. Geologiska Föreningens $i$ Stockholm Förhandlingar 24(5), 309-345.

Grönwall,K. A., 1902b: Bornholms Paradoxideslag og deres Fauna. Danmarks Geologiske Undersøgelse 2(13), 1-231.

Grönwall, K. A. \& Milthers, V., 1916: Beskrivelse til geologisk kort over Danmark, Kortbladet Bornholm. Danmarks Geologiske Undersøgelse 1(13), 1-281.

Gry, H., Jørgart, T. \& Poulsen, V., 1969: Geologi på Bornholm. Varv Ekskursionsfører No 1, København.

Gulbrandsen, R. A., 1966: Chemical composition of phosphorites of the Phosphoria Formation. Geochimica et Cosmochimica Acta 30, 769-778.

Gulbrandsen, R. A., 1969: Physical and chemical factors in the formation of marine apatite. Economic Geology 64,365-382.

Hamilton, E. L. \& Rex, R. W., 1959: Lower Eocene phosphatized globigerina ooze from Silvania Guyot. U.S. Geological Survey Professional Paper 260-W, 785-798.

Hansen, K., 1936: Die Gesteine des Unterkambriums von Bornholm. Danmarks Geologiske Undersøgelse II, 62, 1-194.

Hansen, K., 1937: Sammenlignende Studier over Kambriet i Skåne og paa Bornholm. Meddelelser fra Dansk Geologisk Forening 9(2), 151-183.

Jensen, A., 1977: Character and provenance of the opaque minerals in the Nexø sandstone, Bornholm. Bulletin of the Geological Society of Denmark, 26, 69-76. 
Johnstrup, F., 1874: Oversigt over de Paleozoiske Dannelser På Bornholm. Beretning om det 11:e Skandinaviske Naturforskermøde i Kjøbenhavn 1873, 299-308.

Johnstrup, F., 1891: Abriss der Geologie von Bornholm, als Führer zu der Exkursion der Deutschen Geologischen Gesellschaft nach der Insel Bornholm. Festschrift der Geographischen Gesellschaft zu Greifswald, 1-66.

Kasakov, A. V., 1937: The phosphorite facies and the genesis of phosphorites. Transactions of the Scientific Institute of Fertilizers and Insecto-Fungicides 142, 95-113.

McBride, E. F. \& Folk, R. L., 1977: The Caballos Novaculite revisited: part II: chert and shale members and synthesis. Journal of Sedimentary Petrology 47(3), 1261-1286.

McConnell, D., 1938: A structural investigation of the isomorphism of the apatite group. The American Mineralogist 23, 1-19.

McConnell, D., 1952: The nature of phosphates, teeth and bones. Journal of the Washington Academy of Sciences 42, 36-38.

McConnell, D., 1965: Precipitation of phosphates in sea water. Economic Geology 60, $1059-1062$.

McKelvey, V. E., Swanson, R. W. \& Sheldon, R. P., 1953: The Permian phosphorite deposits of the western United States: 19th International Geological Congress, Algiers, Compte Rendu $11,45-64$.

Marlowe, J. I., 1971: Dolomite, phosphorite, and carbonate diagenesis on a Caribbean Seamount. Journal of Sedimentary Petrology 41(3), 809-827.

Martinsson, A., 1974: The Canbrian of Norden. In: C. H. Holland (ed.), Cambrian of the British Isles, Norden, and Spitsbergen (London, Wiley), 185-283.

Matthews, R. K., 1974: Dynamic stratigraphy. Prentice-Hall, Inc., Englewood Cliffs, New Jersey, 370 pp.

Pevear, D. R., 1966: The estuarine formation of United States atlantic coastal plain phosphorite. Economic Geology 61, 251-256.

Pevear, D. R., 1967: Shallow water phosphorites. Economic Geology 62, 562-575.

Poulsen, C., 1942: Nogle hidtil ukendte Fossiler fra Bornholms Exsulanskalk. Meddelelser fra Dansk Geologisk Forening 10, 212-233.

Poulsen, C., 1967: Fossils from the Lower Cambrian of Bornholm. Det Kongelige Danske Videnskabernes Selskab Matematisk-fysiske Meddelelser 36(2), 1-48.

Poulsen, V., 1963: The Lower Middle Cambrian Kalby-Ler (Kalby Clay) on the island of Bornholm. Biologiske Meddelelser udgivet af Det Kongelige Danske Videnskabernes Selskab 23(14), 1-14.

Poulsen, V., 1966: Cambro-Silurian stratigraphy of Bornholm. Meddelelser fra Dansk Geologisk Forening København 16, 117-137.

Powers, M. C., 1953: A new roundness scale for sedimentary particles. Journal of Sedimentary Petrology 36, 117-119.

Rapson-McGugan, J. E., 1970: The diagenesis and depositional environment of the Permian Ranger Canyon and Mowitch Formations, Ishbel Group, from the southern Canadian Rocky Mountains. Sedimentology 15, 363-417.

Reineck, H. E. \& Singh, I. B., 1973: Depositional Sedimentary Environments, 439 pp. Springer-Verlag, New York.

Rock-color Chart, 1970: Distributed by The Geological Society of America, Boulder, Colorado.

Sorgenfrei, Th., 1957: Rispebjerg Sandstone. In: Centre National de la Recherche Scientifique (ed.), Lexique Stratigraphique International 1, 2d., Danemark, 1.

Teodorovich, G. I., 1961: Authigenic minerals in sedimentary rocks. 120 pp. Consultants Bureau, New York, N.Y.

Walker, Th. R., 1962: Reversible nature of chert-carbonate replacement in sedimentary rocks. American Association of Petroleum Geologists Bulletin 73,237-242. 
